\title{
Gut-homing conventional plasmablasts and CD27- plasmablasts elicited after a short time of exposure to an oral live-attenuated Shigella vaccine candidate in humans
}

\section{Franklin R. Toapanta ${ }^{1,2}$ *, Jakub K. Simon ${ }^{3}$, Eileen M. Barry ${ }^{1,4}$, Marcela F. Pasetti ${ }^{1,5}$, Myron M. Levine $^{1,2,5}$, Karen L. Kotloff ${ }^{1,2,5}$ and Marcelo B. Sztein ${ }^{1,4,5 *}$}

\author{
' Center for Vaccine Development, University of Maryland School of Medicine, Baltimore, MD, USA \\ ${ }^{2}$ Department of Medicine, University of Maryland School of Medicine, Baltimore, MD, USA \\ ${ }^{3}$ PaxVax, Inc. Redwood City, CA, USA \\ ${ }^{4}$ Department of Microbiology and Immunology, University of Maryland School of Medicine, Baltimore, MD, USA \\ ${ }^{5}$ Department of Pediatrics, University of Maryland School of Medicine, Baltimore, MD, USA
}

\section{Edited by:}

Donata Medaglini, University of

Siena, Italy

\section{Reviewed by:}

Emma Slack, ETH Zürich, Switzerland Rita Carsetti, Ospedale Pediatrico Bambino Gesù, Italy

David J. M. Lewis, St George's -

University of London, UK

\section{*Correspondence:}

Franklin R. Toapanta, Center for Vaccine Development, University of Maryland School of Medicine, 685 West Baltimore Street, HSF-1 Room 446, Baltimore, MD 21201, USA e-mail: ftoapanta@medicine.

umaryland.edu;

Marcelo B. Sztein, Center for Vaccine Development, University of Maryland School of Medicine, 685 West

Baltimore Street, HSF-1 Room 480,

Baltimore, MD 21201, USA

e-mail: Msztein@medicine.

umaryland.edu
Currently, there is no licensed Shigella vaccine; however, various promising live-attenuated vaccine candidates have emerged, including CVD1208S ( $\triangle$ guaBA, $\Delta$ set, $\Delta$ sen S. flexneri $2 a)$, which was shown to be safe and immunogenic in Phase 1 clinical trials. Here, we report the immune responses elicited in an outpatient Phase 2 clinical trial in which subjects were vaccinated with CVD 1208S. Oral immunization with CVD 1208S elicited high anti-S. flexneri 2a LPS and IpaB antibody responses as well as an acute plasmablast (PB) infiltration in peripheral blood 7 days after immunization. PB sorted based on their expression of homing molecules confirmed that cells expressing integrin $\alpha 4 \beta 7$ alone or in combination with CD62L were responsible for antibody production (as measured by ELISpot). Furthermore, using high-color flow-cytometry, on day 7 after immunization, we observed the appearance of conventional PB (CPB, CD19dim $\left.\mathrm{CD} 20^{-} \mathrm{CD} 27^{\text {thigh }} \mathrm{CD} 8^{\text {thigh }} \mathrm{CD} 3^{-}\right)$, as well as a PB population that did not express CD27 (CD27- PB; pre-plasmablasts). The pattern of individual or simultaneous expression of homing markers (integrin $\alpha 4 \beta 7, \mathrm{CD} 62 \mathrm{~L}, \mathrm{CXCR3}$, and CXCR4) suggested that CPB cells homed preferentially to the inflamed gut mucosa. In contrast, $~ 50 \%$ CD27- PB cells appear to home to yet to be identified peripheral lymphoid organs or were in a transition state preceding integrin $\alpha 4 \beta 7$ upregulation. In sum, these observations demonstrate that strong immune responses, including distinct PB subsets with the potential to home to the gut and other secondary lymphoid organs, can be elicited after a short time of exposure to a shigella oral vaccine.

Keywords: Shigella, oral vaccine, plasmablasts, homing, B cells

\section{INTRODUCTION}

The intestine constitutes the largest immunological organ in the body and is home to the majority of lymphocytes $(1,2)$. In this organ, pathogens such as Shigella and Salmonella activate antigen presenting cells (APC) [e.g., dendritic cells (DC)] that migrate to mesenteric lymph nodes (MLN) where they stimulate lymphocytes (3). Subsequently, activated lymphocytes migrate to the intestinal lamina propria, as effector immune cells, largely via blood (2, 4-6). Lymphocytes homing to the intestine express both CCR9, a chemokine receptor mediating homing to the small intestine $(1,2,4,7,8)$ and integrin $\alpha 4 \beta 7$ (9), a gut-specific homing receptor that recognizes Mad-CAM1 on the endothelial venules of the intestine. On the other hand, lymphocytes expressing CD62L (L-selectin) home preferentially to peripheral lymph nodes by binding to Gly-CAM1, which is found on high endothelial venules through which lymphocytes enter secondary lymphoid organs (10-12). Expression of these homing markers on lymphocytes is regulated by intestinal DC during antigen presentation (3-6).

Efforts are ongoing to better characterize the intestinally derived immune responses to Shigella infection. This information will be invaluable to guide the development of novel live oral vaccines against a pathogen whose global burden is well-documented $(13,14)$. After Shigella enters the host it infiltrates the gut epithelium, primarily via $\mathrm{M}$ cells (15-17). Innate immunity is often insufficient to clear a Shigella infection, particularly once it enters epithelial cells where this microorganism can move freely inside and between cells (18). As the infection progresses, Shigella activates the adaptive immune system and induces humoral (antibody) and effector $\mathrm{T}$ cell (CMI) responses, as well as memory (B and $\mathrm{T}$ ) responses $(15,17-24)$. Various lines of evidence point to the importance of the B cell compartment in protection against repeated Shigella infections. For one, serotype-specific protection has been demonstrated in field (25-27) and clinical settings (28, 29 ) in humans and in primate studies (30). Serotype-specific IgA and IgG antibodies as well as circulating IgA antibody-secreting cells (ASC) directed against the (LPS) O-antigen have been correlated with protection $(21,23,29-37)$. More recent evidence suggests that antibodies to invasion plasmid antigens (Ipa) also play an important role in protection $(23,24,38-42)$. Among B cells, plasmablasts (PB) and plasma cells (PC) are responsible for 
antibody production/secretion. $\mathrm{PB}$, which are not yet fully differentiated PC, proliferate extensively (43) and actively secrete antibodies while migrating to the target tissues where they will differentiate and home as PC. PB numbers peak in peripheral blood at day 6 or 7 following immunization or infection by Shigella (44) and other pathogens $(43,45-53)$. This transient peak of PB in peripheral blood, which coincides with the acute phase of immune responses, has been termed "acute $\mathrm{PB}$ infiltration" and used to differentiate from steady-state PB $(54,55)$. This "acute PB infiltration" has also been described in secondary infection/vaccination responses around the same time frame (7-9 days). While in a primary infection/vaccination, the "acute $\mathrm{PB}$ infiltration" is evidence of lymphocyte priming; in secondary infection/vaccination, it most likely indicates activation of memory B cells $\left(B_{M}\right)$. PB recently activated in the intestine, either by oral vaccination $(19,20$, 56-59) or intestinal infections (60-62) are identified in circulation as ASC expressing integrin $\alpha 4 \beta 7(62,63)$, implying a preferential homing of these cells to the intestinal lamina propria. Other homing markers, such as CXCR3 and CXCR4, which promote homing to inflamed tissues and bone marrow, respectively, have also been reported in PB cells (64).

Designing novel oral live-attenuated Shigella vaccine candidate strains requires striking an optimal balance between limited reactogenicity and induction of protective, long-lasting immunity. Due to the difficulty in achieving this fine balance, the goal of generating effective oral live-attenuated vaccine strains against Shigella has proven difficult, and occasionally resulted in vaccine-related reactogenicity. No licensed vaccines against Shigella are currently available $(23,24)$; however, various promising live-attenuated oral vaccine candidates have been developed. CVD 1208 and CVD 1208S, developed at the Center for Vaccine Development (CVD) of the University of Maryland, were constructed by introducing precise deletions in the wild-type $S$. flexneri $2 a$ strain $2457 \mathrm{~T}$ (65). Both vaccine strains are impaired in their ability to synthesize guanine nucleotides ( $\triangle g u a B A)$, and lack Shigella enterotoxins (ShET) 1 and 2, encoded by set and sen, respectively. After CVD 1208 showed promising results in clinical trials (66), it was reconstructed using animal-free media to comply with regulatory requirements for use in humans, and shown to be well-tolerated and immunogenic in Phase 1 clinical trials (65). Herein, we report the results of a Phase 2 clinical trial in which a new lot of CVD 1208 S grown in an animal product-free medium different from the one used previously. After the first vaccine dose, some subjects experienced fever and/or diarrhea, which was attributed to the new soy-based medium used to grow CVD 1208S. This prompted the initiation of antibiotic treatment 1-4 days post-immunization. Here, we describe the humoral immune responses and the homing patterns of $\mathrm{PB}$ cells elicited in these volunteers, as well as a PB population that lacks CD27 expression $\left(\mathrm{CD} 27^{-} \mathrm{PB}\right)$ and appears to migrate to lymphoid organs different from "conventional" PB (CPB) cells.

\section{MATERIALS AND METHODS \\ SUBJECTS AND STUDY DESIGN}

Healthy male and non-pregnant female volunteers aged 1849 years were recruited from the Baltimore/Washington, DC area for this randomized, placebo-controlled, and double-masked clinical trial (Table 1). Volunteers were required to be in good health
Table 1 | Summary of the demograpics of the volunteers recruited for the study.

\begin{tabular}{lccc}
\hline & $\begin{array}{c}\text { Vaccine } \\
\left(\boldsymbol{n}^{\mathbf{a}=17)}\right.\end{array}$ & $\begin{array}{c}\text { Placebo } \\
(\boldsymbol{n}=\mathbf{3})\end{array}$ & $\begin{array}{c}\text { Total } \\
(\boldsymbol{n}=\mathbf{2 0})\end{array}$ \\
\hline Age $^{\mathbf{b}}$ & 37.2 & 32.3 & 36.5 \\
$\left(95 \% \mathrm{Cl}^{\mathrm{C}}\right)$ & $(33.2-41.1)$ & $(12.1-52.6)$ & $(32.8-40.1)$ \\
$\mathbf{W e i g h t}^{\mathbf{d}}$ & 182 & 222 & 188 \\
$(95 \% \mathrm{Cl})$ & $(165-200)$ & $(24-421)$ & $(168-208)$ \\
$\mathbf{B M I}^{\mathbf{e}}$ & 28 & 32 & 28 \\
$(95 \% \mathrm{Cl})$ & $(25-31)$ & $(1-62)$ & $(25-32)$ \\
Female $^{\mathbf{f}}$ & 35 & 0 & 30 \\
$(95 \% \mathrm{Cl})$ & $(13-58)$ & $(0-0)$ & $(10-50)$ \\
Black $^{\mathbf{f}}$ & 82 & 67 & 80 \\
$(95 \% \mathrm{Cl})$ & $(64-100)$ & $(13-100)$ & $(62-98)$ \\
Asian $^{\mathbf{f}}$ & 0 & 33 & 5 \\
$(95 \% \mathrm{Cl})$ & $(0-0)$ & $(0-87)$ & $(0-15)$ \\
White $^{\mathbf{f}}$ & 18 & 0 & 15 \\
$(95 \% \mathrm{Cl})$ & $(0-36)$ & $(0-0)$ & $(0-31)$ \\
\hline
\end{tabular}

\footnotetext{
${ }^{a}$ Number of volunteers.

${ }^{b}$ Mean in years.

${ }^{\circ}$ Confidence Interval.

${ }^{a}$ Mean in pounds.

${ }^{e}$ Body mass index.

${ }^{f}$ Percentage.
}

as evidenced by medical history, physical examination, and laboratory evaluation, as previously described $(65,66)$. Serial cohorts of volunteers who satisfied eligibility criteria and provided informed, written consent were randomly allocated 5:1 to receive vaccine ( $n=50)$ or placebo $(n=10)$. Each subject was scheduled to ingest a dose of vaccine or placebo on days 0,28 , and 56 . An independent safety monitor was charged with reviewing safety data after each dose to recommend whether additional dosing was acceptable. This study was approved by the Institutional Review Board and registered on ClinicalTrials.gov (identifier NCT00866476). In this report, we include the results of two cohorts (20 volunteers) who received a single dose of CVD $1208 \mathrm{~S}(n=17)$ or placebo $(n=3)$.

\section{Halting rules}

Antibiotic treatment (ciprofloxacin $500 \mathrm{mg}$ by mouth twice daily for 5 days) was not to be routinely administered to subjects unless specific reactogenicity events occurred and were considered to be vaccine-related: (1) one or more subjects experienced a serious adverse reaction, or (2) two or more subjects experienced any of the following adverse reactions: (a) fever $>39^{\circ} \mathrm{C}$; (b) passage of $>5$ diarrheal stools per day or requiring $>2 \mathrm{~L}$ of intravenous hydration); or (c) passage of moderate dysentery ( $>2$ dysenteric stools per day). If these events occurred, under advisement of the Safety Monitoring Committee, further doses of vaccine would not be administered.

\section{CVD1208S VACCINE CONSTRUCTION AND PREPARATION}

CVD 1208S ( $\triangle$ guaBA, $\Delta s e n, \Delta s e t)$ was constructed from wildtype S. flexneri 2a strain $2457 \mathrm{~T}$ by a series of allelic exchange 
reactions using suicide plasmid deletion cassette technology as previously described (65). The vaccine was administered as a freshly harvested formulation. The inocula were derived from frozen master cell banks (MCB) prepared as previously described (65), except for the change in solid media from Hy-Soy (Kerry BioScience, Norwich, NY, USA) to APF Athena Lennox (Athena Enzyme Systems, Baltimore, MD, USA). In short, a frozen vial of master seed was plated onto APF LB agar plates (Lennox) containing Congo red dye $(0.01 \%)$ (Sigma-Aldrich, St. Louis, MO, USA) and guanine (0.005\%) (Sigma-Aldrich) (no antibiotics). After incubation $\left(18-24 \mathrm{~h}, 37^{\circ} \mathrm{C}\right)$, single Congo red positive colonies were confirmed to be Shigella using antiserum (Denka Seiken, Niigata, Japan). Several colonies were suspended in sterile saline, inoculated into guanine-supplemented APF LB agar plates, incubated overnight $\left(37^{\circ} \mathrm{C}\right)$ in the absence of antibiotics and harvested into sterile phosphate buffered saline (PBS, pH 7.4) (Sigma-Aldrich). The bacterial suspension was diluted (sterile PBS) to have an O.D. $(660 \mathrm{~nm})$ corresponding to the desired bacterial count per milliliter. The inocula were used within $4 \mathrm{~h}$ of preparation. The geometric mean of replicate colony counts performed before and after vaccination confirmed that the expected inoculum $\left(1 \times 10^{9} \mathrm{CFU}\right.$ per milliliter) of vaccine had been attained. Placebo consisted of buffer solution mixed with cornstarch USP (ScicenceLab.com Inc., Houston, TX, USA) added to match the turbidity of the vaccine (65).

Twenty outpatient volunteers were fasted $90 \mathrm{~min}$ before drinking $120 \mathrm{ml}$ of a solution containing $2 \mathrm{~g}$ of $\mathrm{NaHCO}_{3}$ in $150 \mathrm{ml}$ distilled water to buffer gastric acid. One minute later, the volunteers took the vaccine (at $\sim 10^{9} \mathrm{cfu}$ ) in the remaining $30 \mathrm{ml}$ of buffer or placebo (buffer alone). The volunteers were fasted an additional 90 min after vaccination. For the remainder of the day of vaccination and for the next 6 days, they recorded signs and symptoms onto a standardized diary form which were graded for severity, including their daily oral temperature, the occurrence of constitutional symptoms (headache, anorexia, malaise, and abdominal cramps), vomiting, and the character of all stools passed as either formed or loose (defined as stools, which take the shape of the container) and whether they contained visible blood. They returned to the study center on days 3 and 7 after vaccination to review diary cards. Antibiotics were given only in the event of unacceptable reactogenicity.

\section{SERUM ANTIBODY RESPONSES}

IgA and IgG antibody titers against LPS and recombinant Shigella IpaB were measured in serum before vaccination as well as on days 7,14 , and 28 post-immunization by enzyme-linked immunosorbent assay (ELISA) as previously described (65). Titers were calculated from linear regression curves and expressed as the reciprocal serum dilution that produced an O.D. of 0.2 above the blank, in ELISA Units (EU) per milliliter. Seroconversion was defined as a fourfold or higher rise in antigen-specific serum antibody postvaccination compared to the pre-vaccination titer. The LPS from S. flexneri 2a LPS was purified by the hot aqueous phenol extraction method of Westphal (67) and the Shigella IpaB protein was purified as recombinant proteins expressed in E. coli as previously described $(20,21,65,68)$.

\section{ANTIBODY-SECRETING CELLS}

In order to evaluate intestinal priming by CVD 1208S, antigenspecific circulating IgA and IgG ASC were measured before (day 0 ) and 7 days after vaccination by enzyme-linked immunospot assay (ELISpot) as previously described $(65,66)$. In short, nitrocellulose plates (Millipore, Billerica, MA, USA) were coated with Shigella antigens including S. flexneri 2 a LPS and Shigella IpaB $(0.1 \mathrm{mg} / \mathrm{ml})$, which were prepared according to previously published methods $(20,21,65,68)$. Coated plates were washed $(3 \times)$ with PBS and blocked with 10\% FBS RPMI (Gibco, Grand Island, $\mathrm{NY}$, USA) for $2 \mathrm{~h}\left(5 \% \mathrm{CO}_{2}, 37^{\circ} \mathrm{C}\right)$. Peripheral blood mononuclear cells (PBMC) were then seeded $\left(2.5 \times 10^{5}\right.$ per well) in quadruplicate and incubated for $14-16 \mathrm{~h}\left(5 \% \mathrm{CO}_{2}, 37^{\circ} \mathrm{C}\right)$. Subsequently, plates were washed with PBS-Tween $(0.05 \%)$ and HRP-labeled goat anti-human IgA (1:2000) (Jackson ImmunoResearch Laboratories, West Grove, PA, USA) as well as IgG (1:1000) (Jackson ImmunoResearch Laboratories) were added to the respective plates and incubated for $1 \mathrm{~h}\left(37^{\circ} \mathrm{C}\right)$. Following a wash step, the 3-amino-9 ethylcarbazole C (AEC) substrate (Sigma-Aldrich) was added and plates incubated 10-20 min in the dark. Finally, plates were washed three times with distilled water to stop the reaction. Positive ELISpot responses were defined as a post-vaccination counts per $10^{6}$ PBMC that are at least three standard deviations (SD) above the mean pre-vaccination count for all subjects (in the $\log$ metric); a minimum of eight cells were required, which corresponds to the mean of medium negative control wells (two spots) plus three SD (66).

\section{CELL SORTING STRATEGY TO EVALUATE EXPRESSION OF HOMING MOLECULES BY SHIGELLA-SPECIFIC ASC}

Freshly isolated PBMC were stained with monoclonal antibodies to CD19-PE-Cy7 (clone J3-119, Beckman-Coulter - BC), CD27-PECy5 (Clone 1A4CD27, BC), CD62L-PE (Clone Dreg-56, Becton-Dickinson - BD), and integrin $\alpha 4 \beta 7$ (Clone ACT-1, Millenium: The Takenda Oncology Co., Cambridge, MA, USA) conjugated to Alexa 488 using an Alexa labeling kit (Molecular Probes). Cells were then simultaneously sorted into four populations: $\mathrm{B}$ naïve (Bn, CD19+ ${ }^{+}$D27 $\left.7^{-}\right)$, (P) B memory $\left(\mathrm{B}_{\mathrm{M}}, \mathrm{CD} 19^{+} \mathrm{CD} 27^{+}\right)$ expressing CD62L but not integrin $\alpha 4 / \beta 7\left(\mathrm{CD}^{2} \mathrm{~L}^{+} \alpha 4 \beta 7^{-}\right)(\mathrm{M})$ $\mathrm{B}_{\mathrm{M}}$ expressing integrin $\alpha 4 \beta 7$ but not CD62L $\left(\mathrm{CD}_{2} \mathrm{~L}^{-} \alpha 4 \beta 7^{+}\right)$, or $(\mathrm{M} / \mathrm{P}) \mathrm{B}_{\mathrm{M}}$ expressing both integrin $\alpha 4 \beta 7$ and CD62L $\left(\mathrm{CD} 62 \mathrm{~L}^{+}\right.$ $\left.\alpha 4 / \beta 7^{+}\right)$. Four-way sorting was performed in a MoFlo flow cytometer/cell sorter system (Beckman-Coulter). Purities of the sorted populations were $84.1-94 \%$. The presence of Shigellaspecific IgG and IgA ASC in each sorted population was measured as described above (see Antibody-Secreting Cells). The results are expressed as number of spots per $1 \times 10^{6}$ cells.

\section{PB CELL DETERMINATIONS BY MULTICHROMATIC FLOW CYTOMETRY}

Peripheral blood mononuclear cells were isolated immediately after blood draws by density gradient centrifugation $(69,70)$. Freshly isolated PBMC were re-suspended in complete media [RMPI (Gibco, NY, USA) supplemented with 10\% fetal bovine serum (FBS) (Gemini Bioproducts, West Sacramento, CA, USA), $2 \mathrm{mM}$ L-glutamine (Gibco, Grand Island, NY, USA), $1 \times$ nonessential amino acids (Gibco, Grand Island, NY, USA), $10 \mathrm{mM}$ HEPES (Gibco, Grand Island, NY, USA), 2.5 mM Sodium pyruvate 
(Lonza, Walkersville, MD, USA), $100 \mathrm{U} / \mathrm{ml}$ Penicillin, $100 \mu \mathrm{g} / \mathrm{ml}$ streptomycin (Sigma-Aldrich, St. Louis, MO, USA), $50 \mu \mathrm{g} / \mathrm{ml} \mathrm{Gen-}$ tamicin (Gibco, Grand Island, NY, USA)] and stained for flow cytometry in $12 \mathrm{~mm} \times 17 \mathrm{~mm}$ tubes using methods previously described $(69,71)$. Briefly, $1 \times 10^{6}$ cells were plated and washed with flow cytometry staining (FC) buffer (4\% FCS, $1 \times$ PBS) and 0.02 Sodium Azide). Cells were blocked with human IgG $(50 \mu \mathrm{l}$ of a $600 \mu \mathrm{g} / \mathrm{ml}$ solution in FC buffer) (Sigma, St Louis, MO, USA) and following one wash, stained with antibody cocktails prepared in FC buffer. Antibodies used included: IgD-FITC (Clone IA6-2,BD), CD38-PE (Clone HB7, BD), CD19-ECD (Clone J3119; BC), CXCR3-PE-Cy5 (Clone 1c6/CXCR3, BD), CD20-PECy7 (Clone L27, BD), CD3-Pacific Blue (Clone UCHT1, BD), CD14 (Clone TuK4, Caltag), integrin $\alpha 4 \beta 7$-Alexa 647 (Clone ACT1); CD27-APC-Alexa700 (clone: 1A4CD27; BC), CD62L-APCAlexa750 (Clone Dreg-56, Caltag), IgG-Biotin (Clone 12G5, BD), and IgA-Biotin (Clone G20-359, BD). Staining was performed at $4^{\circ} \mathrm{C}$ in the dark for $30 \mathrm{~min}$. After washing the cells $(2 \times$ with FC buffer), Pacific Orange-Streptavidin was added to each sample (Invitrogen, Carlsbad, CA, USA) (30 min) followed by two washes. Stained cells were fixed with 1\% PFA in PBS and samples collected in a custom LSRII flow cytometer analyzer (BD, USA). Samples were analyzed using a FlowJo software package (Tree Star, USA).

\section{STATISTICAL METHODS}

For each randomized group, we calculated the proportion of subjects manifesting solicited clinical reactions and specific immunologic responses to vaccination. The geometric means and median values were calculated for serum antibody levels and ASC. Prevaccination and post-vaccination antibody titers and ASC counts at different time points were evaluated by one-way ANOVA with Dunnett's post-test using day 0 as comparator. Post-vaccination ASC counts (D7) and serum antibody titers (D14) in each reactogenicity group as well as homing of sorted ASC were compared using the Mann-Whitney test. The percentages of CPB cells and $\mathrm{CD} 27^{-} \mathrm{PB}$ cells, pre-vaccination and post-vaccination were compared using the Mann-Whitney test. Spearman's correlation coefficient was used to assess relationships between ASC (day 7) and the percentage of CPB cells and CD27- PB cells (day 7). The same correlation test was used to assess the relationship between antibody titers and the percentage of $\mathrm{CPB}$ or $\mathrm{CD} 27^{-} \mathrm{PB}$ cells (day 7). Comparison of multiple homing markers expressed by $\mathrm{CPB}$ and $\mathrm{CD}^{-} 7^{-} \mathrm{PB}$ cells was done by one-way ANOVA with Bonferroni's post-test. Microsoft Excel, GraphPad Prism, NCSS, and STATA were used for statistical analysis. All hypotheses were evaluated using two-sided tests. Two-sided $p$-values $<0.05$, without adjustment for multiple comparisons, were considered statistically significant.

\section{RESULTS}

\section{CLINICAL OBSERVATIONS}

Two cohorts were inoculated. Cohort 1 was composed of seven vaccinees (estimated inoculum $2.5 \times 10^{9} \mathrm{cfu}$ ) and one placebo recipient. Cohort 2 was composed of 10 vaccinees (estimated inoculum $3.3 \times 10^{9} \mathrm{cfu}$ ) and two placebo recipients. Cohorts were immunized 2 days apart. The occurrence of fever (17.6\%), diarrhea (23.5\%), and/or vomiting (5.8\%) (Table 2) met criteria for antibiotic administration. Cohort 1 and 2 received antibiotics 4 and 1-2 days after immunization, respectively. No further vaccinations were administered. Even though the study was terminated early and no more cohorts vaccinated, safety follow-ups, stool cultures for fecal shedding of vaccine (unpublished data), and immunologic assays on days 7 and 28 were collected in the two cohorts that received the vaccine.

\section{ANTI-SHIGELLA HUMORAL IMMUNE RESPONSES INDUCED BY CVD $1208 S$}

CVD 1208S induced significant rises in anti-LPS IgA antibody titers compared to baseline at 7 and 14 days post-immunization, which began to diminish by day 28 (Figure 1; Table 2). By day 14 (peak day of anti-LPS IgA antibody production), 70.6\% (12 of 17) of vaccinated volunteers had seroconverted (less than or equal to fourfold-increase (FI) over day 0) (Figure 1A). In contrast, placebo recipients did not develop anti-LPS IgA antibodies at any time point (Figure 1D). LPS-specific PB IgA ASC were detected 7 days post-immunization in all vaccinees (Figure 1B) but in none of the placebo recipients (data not shown). Moreover, LPS-specific IgA ASC was positively correlated with anti-LPS IgA antibody titers (at peak - D14) (Spearman's correlation) (Figure 1C).

CVD 1208S also induced elevated anti-LPS IgG antibody titers; however, these were less robust than the IgA responses (Figure 1; Table 2). By day 14 (IgG peak), $41 \%$ of the vaccinated volunteers (7 of 17) had seroconverted (Figure 1E). IgG LPS-ASC were also identified on day 7 (Figure 1F) and the presence of these cells also correlated anti-LPS IgG (FI) at day 14 (Spearman's correlation) (Figure 1G). Placebo recipients did not develop anti-LPS IgG responses at any time point (Figure $\mathbf{1 H}$ ).

CVD 1208S also evoked antibodies (IgA and IgG) against the protein antigen IpaB; $35.3 \%$ (6 of 17) of the vaccinated volunteers seroconverted to IgA and $52.9 \%$ ( 9 of 17) to IgG by day 14 postimmunization (Figures 2A,E, respectively). Anti-IgA IpaB-ASC were also increased in peripheral blood (day 7) (Figure 2B) and the frequency of these cells correlated with the anti-IpaB antibody titers (day 7 FI over day 0) (Spearman's correlation) (Figure 2C). On the other hand, anti-IgG IpaB-ASC were identified in only two volunteers (day 7) (Figure 2F) and no correlation with antibody titers was identified (Figure 2G).

The immune responses of volunteers that showed reactogenicity were compared to the vaccinees who remained asymptomatic. Although vaccinees without symptoms showed somewhat higher IgG and IgA seroconversions and ASC responses than vaccinees who exhibited reactogenicity, these differences did not reach a point of statistical significance (data not shown). Furthermore, to determine if the length of exposure to the vaccine had effects on the strength of the immune responses elicited, we compared cohorts 1 and 2. No significant differences in antibody titer or ASCs to LPS or IpaB were identified between these cohorts (data not shown).

\section{ASC EXPRESSING INTESTINAL HOMING MARKERS PRODUCE SHIGELLA-SPECIFIC ANTIBODIES}

To study the homing potential and antigen-specific production of $\mathrm{PB}$ cells (ASC), freshly isolated PBMC from day 7 postimmunization were fluorescently sorted into four populations of $B$ 

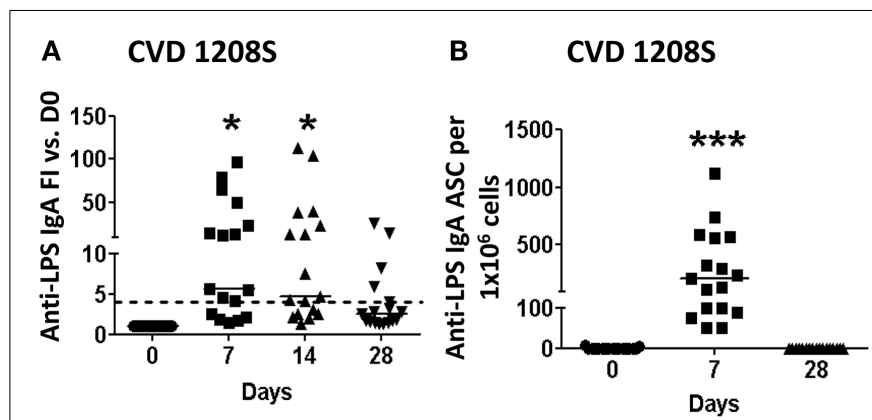

E CVD 1208S

F CVD 1208S
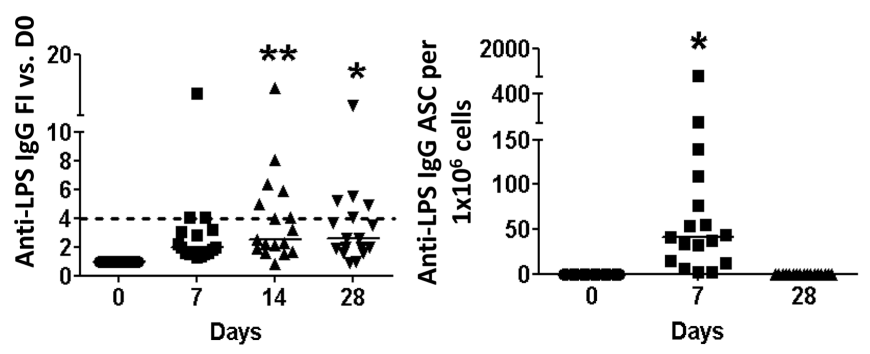

FIGURE 1 | Anti-LPS IgA and IgG immune responses to CVD 1208 S.

(A,E) Anti-LPS IgA and IgG serum levels before and at days 7, 14, and 28 after immunization. Seroconversion was defined as $a \geq 4$-fold-increase (dotted line) in antigen-specific antibody titers compared to day 0. (B,F) ASC anti-LPS IgA and IgG (ELISpot) before and at days 7 and 28 after immunization.

(C,G) Spearman's correlation between anti-LPS IgA and IgG antibody titers
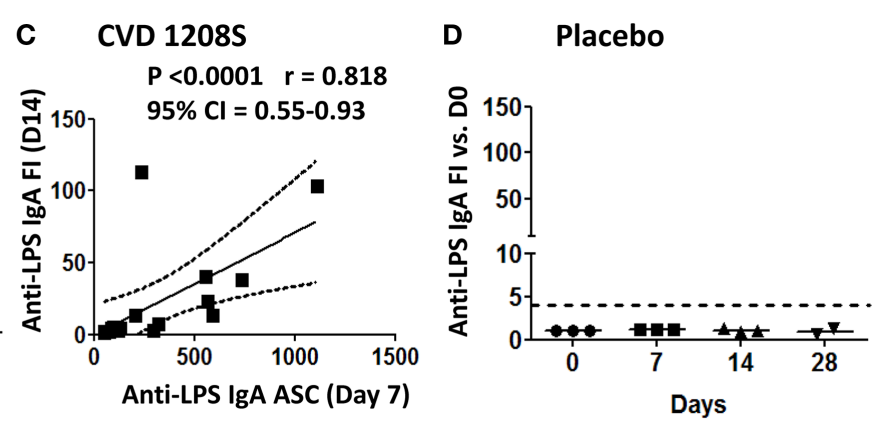

G

CVD 1208S

H Placebo
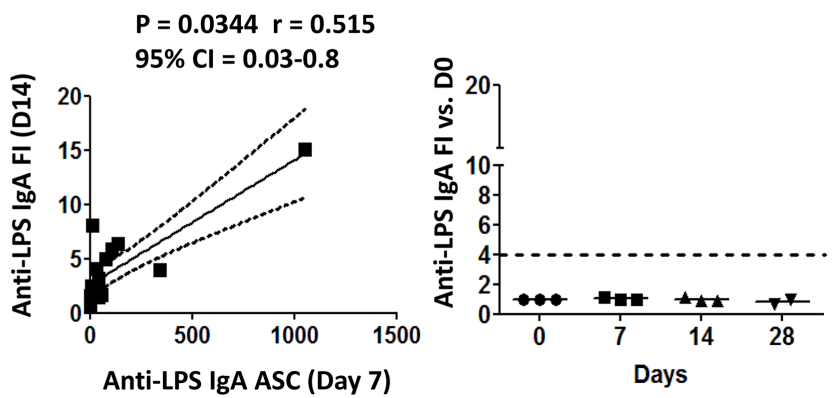

(fold-increase at day 14) and ASC (day 7). (D,H) Sera anti-LPS IgA and IgG in placebo volunteers $(n=3)$. In all plots each symbol indicates an individual volunteer. Dotted lines indicate seroconversion (fourfold-increase over day 0). Horizontal bars represent the median in all graphs. Asterisks show statistical significance when compared to day $0\left({ }^{*} p<0.05 ;{ }^{*} p<0.005\right.$;

$\left.{ }^{* * *} p<0.0005\right)$. cells $\left(\mathrm{CD} 19^{+}\right)$based on the expression of $\mathrm{CD} 27$ and homing markers (integrin $\alpha 4 \beta 7$ or CD62L) (Figure 3A). B cells expressing CD27 and integrin $\alpha 4 \beta 7$, but not $\mathrm{CD} 62 \mathrm{~L}$ have the potential to migrate to the gut mucosa (M). On the other hand, B cells expressing CD27 and CD62L, but not integrin $\alpha 4 \beta 7$ migrate to peripheral lymphoid organs (P). Finally, B cells expressing CD27, integrin $\alpha 4 \beta 7$, and CD62L have dual migration potential (M/P). Sorted cells were then assayed for antibody production to specific Shigella-LPS by ELISpot. The results indicated that cells expressing integrin $\alpha 4 \beta 7$ alone $(\mathrm{M})$ or in combination with CD62L (M/P), but not in those expressing only CD62L (P), were responsible for production of specific anti-Shigella-LPS IgA and IgG antibodies (Figures 3B-E). Control groups included naïve B cells $\left(\mathrm{CD} 19^{+} \mathrm{CD} 27^{-}\right)$that did not produce antigen-specific antibodies (data not shown). Similar results, albeit of lower intensity, were observed in the prior Phase 1 clinical trial (CVD 24000) (65) in which subjects were immunized with CVD 1208 S grown in Hy-Soy agar (Figures 3F-I).

\section{INCREASE IN THE FREQUENCY OF CONVENTIONAL PLASMABLASTS AND CD27-PLASMABLASTS FOLLOWING ORAL IMMUNIZATION WITH CVD 1208S}

Multichromatic flow cytometry was used to further analyze the expression of homing markers in PB cells. This technique allowed simultaneous evaluation of multiple homing markers, including integrin $\alpha 4 \beta 7$, CD62L, CXCR3, and CXCR4 as well as the activation marker HLA-DR. CPB cells were identified in freshly isolated PBMC and defined as $\mathrm{CD} 19^{\mathrm{dim}} \mathrm{CD} 20^{-} \mathrm{CD} 27^{+ \text {(high) }} \mathrm{CD} 38^{+ \text {(high) }}$
(Figure 4). These cells did not express surface Igs ( $\operatorname{IgD}$, IgG, and IgA, data not shown). Interestingly, another population of $\mathrm{PB}$ cells that lacked expression, $\mathrm{CD} 27$ (henceforth named CD27 ${ }^{-} \mathrm{PB}$ ) was also observed. Similar to CPB cells, CD27 ${ }^{-}$PB cells did not express surface Igs (data not shown). Moreover, these cells were less frequent than $\mathrm{CPB}$ at day 0 (average fourfold lower frequency) (Figure 4 and data not shown). $\mathrm{CPB}$ and $\mathrm{CD} 27^{-} \mathrm{PB}$ cells showed a basal expression of HLA-DR as well as homing markers CD62L and integrin $\alpha 4 \beta 7$. Low basal expression of the homing markers CXCR3 and CXCR4 was also observed in both CPB and CD27$\mathrm{PB}$ cells (Figure 4). On day 7 post-vaccination, a statistically significant increase in the percentage of $\mathrm{CPB}$ and $\mathrm{CD} 27^{-} \mathrm{PB}$ cells (as percentage $\%$ of $\mathrm{CD} 19^{+} \mathrm{CD}^{-}$cells), compared to day 0 , was identified (Figure 5). However, CPB showed a higher increase than CD27- $\mathrm{PB}$ cells (4-fold vs. 2.5-fold, respectively) (Figures 5A-C). By day 28 , the percentage of $\mathrm{CPB}$ and $\mathrm{CD} 27^{-} \mathrm{PB}$ cells had returned to pre-vaccination levels (Figures 5B,C). CPB and CD27- $\mathrm{PB}$ cells from placebo immunized volunteers did not show changes at any of the time points examined (data not shown).

Plasmablast cells have been reported to correlate with antibody production (Figures 2-4) (53, 72). However, because flow cytometry does not allow evaluation of antigen-specificity of these cells, we evaluated the relationship between the presence of $\mathrm{PB}$ cells and antigen-specific ASC by Spearman's correlations. As expected, anti-LPS-ASC (IgA and IgG) correlated significantly with CPB cells (day 7, $P<0.05$ ). Interestingly, the same correlation was found with $\mathrm{CD} 27^{-}$PBs (Table 3). 
Table 2 | Reactogenicity and humoral responses in vaccinated volunteers and placebo controls

\begin{tabular}{|c|c|c|c|c|c|c|c|c|c|c|c|c|c|}
\hline & & \multirow[t]{3}{*}{ ID } & \multicolumn{3}{|c|}{ Reactogenicity } & \multicolumn{8}{|c|}{ Humoral immure responses } \\
\hline & & & \multirow{2}{*}{$\begin{array}{c}\text { Fever } \\
{ }^{\circ} \mathrm{C} \\
(\text { Day })^{a}\end{array}$} & \multirow{2}{*}{$\begin{array}{c}\text { Vomiting } \\
\text { \#Episodes }^{\text {b }} \\
\text { (Day) }\end{array}$} & \multirow{2}{*}{$\begin{array}{c}\text { Loose Stools } \\
\text { \#Episodes } \\
\text { (Day) }\end{array}$} & \multicolumn{2}{|c|}{ Anti-LPS IgA } & \multicolumn{2}{|c|}{ Anti-LPS lgG } & \multicolumn{2}{|c|}{ Anti-IpaB lgA } & \multicolumn{2}{|c|}{ Anti-IpaB lgG } \\
\hline & & & & & & $\begin{array}{c}\text { ASC }^{c} \\
\text { (Day 7) }\end{array}$ & $\begin{array}{l}\text { Ab titer Fld } \\
\text { (Day 14) }\end{array}$ & $\begin{array}{c}\text { ASC } \\
\text { (Day 7) }\end{array}$ & $\begin{array}{c}\text { Ab titer FI } \\
\text { (Day 14) }\end{array}$ & $\begin{array}{c}\text { ASC } \\
\text { (Day 7) }\end{array}$ & $\begin{array}{c}\text { Ab titer FI } \\
\text { (Day 14) }\end{array}$ & $\begin{array}{c}\text { ASC } \\
\text { (Day 7) }\end{array}$ & $\begin{array}{c}\text { Ab titer FI } \\
\text { (Day 14) }\end{array}$ \\
\hline \multirow{17}{*}{ 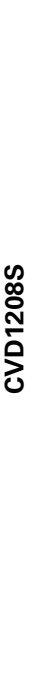 } & & 1 & & & & 120 & 3.1 & 15 & 2.3 & 0 & 1.2 & 0 & 1.0 \\
\hline & $r$ & 2 & & & & 323 & 7.5 & 6 & 2.5 & 0 & 1.1 & 0 & 10.9 \\
\hline & t & $3^{f}$ & $38.8(1)$ & & $5 / 4(1 / 2)$ & 98 & 4.7 & 41 & 1.5 & 0 & 155.3 & 0 & 17.9 \\
\hline & 동 & 4 & & & $4(2)$ & 1114 & 103.6 & 1052 & 15.1 & 107 & 14.2 & 0 & 22.7 \\
\hline & & 6 & & & & 556 & 39.9 & 12 & 8.1 & 0 & 1.5 & 0 & 11.3 \\
\hline & & 7 & & & $3(1)$ & 592 & 13.0 & 139 & 6.4 & 0 & 1.3 & 0 & 2.0 \\
\hline & \multirow{11}{*}{$\begin{array}{l}N \\
\frac{1}{0} \\
\frac{C}{0} \\
ن\end{array}$} & 8 & & & & 208 & 13.5 & 44 & 3.2 & 28 & 2.4 & 11 & 2.3 \\
\hline & & 9 & & & & 566 & 22.9 & 77 & 5.0 & 4 & 1.5 & 0 & 1.6 \\
\hline & & 10 & & & & 50 & 1.3 & 2 & 1.6 & 0 & 0.9 & 0 & 1.1 \\
\hline & & 11 & & & & 88 & 4.1 & 37 & 2.1 & 26 & 2.0 & 13 & 1.1 \\
\hline & & 14 & & & & 76 & 2.1 & 55 & 1.7 & 40 & 4.2 & 0 & 6.7 \\
\hline & & 15 & & & & 298 & 2.6 & 109 & 5.9 & 0 & 1.0 & 0 & 0.5 \\
\hline & & 16 & & & & 51 & 2.0 & 2 & 0.8 & 56 & 2.8 & 0 & 2.2 \\
\hline & & 17 & $38.2(1)$ & & & 130 & 4.3 & 32 & 2.2 & 248 & 46.2 & 0 & 138.7 \\
\hline & & 18 & & & & 236 & 113.3 & 34 & 4.1 & 0 & 1.0 & 0 & 6.5 \\
\hline & & 19 & $39.3(1)$ & $>5 / 5(1 / 2)$ & $8 />5(1 / 2)$ & 98 & 2.5 & 54 & 1.9 & 400 & 41.0 & 0 & 198.3 \\
\hline & & 20 & & & & 738 & 38.2 & 342 & 4.0 & 288 & 106.0 & 0 & 94.5 \\
\hline \multirow{3}{*}{\multicolumn{2}{|c|}{$\begin{array}{l}\circ \\
\frac{0}{ \pm} \\
\frac{\pi}{\alpha}\end{array}$}} & 5 & & & & 0 & 1.3 & 0 & 1.1 & 0 & 1.2 & 0 & 1.1 \\
\hline & & 12 & & & & 0 & 1.1 & 0 & 0.9 & 0 & 1.0 & 0 & 1.0 \\
\hline & & 13 & & & & 0 & 0.9 & 0 & 0.9 & 0 & 1.5 & 0 & 0.5 \\
\hline
\end{tabular}

${ }^{a}$ Day(s) on which the clinical sign was recorded.

${ }^{b}$ Episodes in $24 \mathrm{~h}$.

${ }^{c}$ ASC per $1 \times 10^{6}$ cells on day 7 post-immunization. Bolded results indicate $>8$ spots per $1 \times 10^{6}$ cells.

${ }^{d}$ Antibody titer fold-increase (Fl) at peak post-immunization. Bolded results indicate $>$ fourfold-increase (seroconversion).

${ }^{f}$ This volunteers reported fever of $39^{\circ} \mathrm{C}$ and six loose stools on the phone, but recorded $38.8^{\circ} \mathrm{C}$ and five stools in the diary.

CVD $1208 S$ INCREASED EXPRESSION OF INTEGRIN $\alpha 4 \beta 7$, CXCR3, AND HLA-DR IN CPB AND CD27-PB CELLS

Expression of CD62L and integrin $\alpha 4 \beta 7$ was evaluated in $\mathrm{CPB}$ and $\mathrm{CD}^{-} 7^{-} \mathrm{PB}$ cells (Figures 6 and 7, respectively). Using these markers, four different populations (P, M/P, M, and DN), each one with a different homing (migration) potential, were identified (Figure 6). On day 7 post-immunization, $\mathrm{CPB}$ and $\mathrm{CD}^{-} 7^{-} \mathrm{PB}$ from vaccinated volunteers showed a significant increase in the expression of integrin $\alpha 4 \beta 7(\mathrm{M})$ and down-regulation of CD62L (P) (Figures 6A,B). The percentage of cells with dual migration potential $(\mathrm{M} / \mathrm{P})$ increased only in $\mathrm{CPB}$ (Figures $6 \mathbf{B}$ and $7 \mathbf{B}$ ). By day 28, expression of integrin $\alpha 4 \beta 7$ and CD62L had returned to their basal levels (Figures 6A,B and 7A,B). In contrast, these markers remained unaltered in placebo recipients at every time point assayed (Figures $\mathbf{6 A , C}$ and $\mathbf{7 C}$ ). Expression of the chemokine receptor CXCR3 and HLA-DR were also significantly elevated in $\mathrm{CPB}$ and $\mathrm{CD} 27^{-} \mathrm{PB}$ cells on day 7 post-immunization and returned to pre-vaccination levels by day 28 (Figure 8). Expression of CXCR4 remained unchanged throughout the study (data not shown). Additionally, expression of integrin $\alpha 4 \beta 7, \mathrm{CD} 62 \mathrm{~L}$, and CXCR3 alone or in combinations was assayed in CPB and $\mathrm{CD}^{-} \mathrm{PB}$ cells. This analysis was performed only on day 7 because this is the time point at which these markers showed significant changes. Expression of CXCR4 was excluded from the analysis since this marker did not show significant changes at the time points measured. The results indicated that $\mathrm{CPB}$ cells preferentially up-regulated integrin $\alpha 4 \beta 7$ alone and expression of this marker alone was statistically significant $(p<0.0005)$ when compared to all the other possible combinations, except for cells co-expressing integrin $\alpha 4 \beta 7 / C X C R 3$ (Figure 9A). CD27- PB cells also preferentially up-regulated integrin $\alpha 4 \beta 7$ alone and this group was statistically significant compared to all other groups (except for $\alpha 4 \beta 7^{-} \mathrm{CD}^{2} 2 \mathrm{~L}^{-} \mathrm{CXCR}^{-}$) (Figure 9B). However, this group (integrin $\alpha 4 \beta 7$ alone) did not represent the most abundant cells since $\mathrm{CD} 27^{-}$PB that did not express any of the assayed homing markers, was the most abundant and statistically significantly different $(p<0.0005)$ from all other groups (including integrin $\alpha 4 \beta 7$ alone).

\section{EFFECT OF REACTOGENICITY AND LENGTH OF EXPOSURE TO CVD $1208 \mathrm{~S}$ ON CPB AND CD27- PB CELLS}

To determine if reactogenicity was associated with the frequency of $\mathrm{CPB}$ and $\mathrm{CD} 27^{-} \mathrm{PB}$ cells, we compared the percentage increases of these cells (day 7 post-immunization) between vaccinees who 


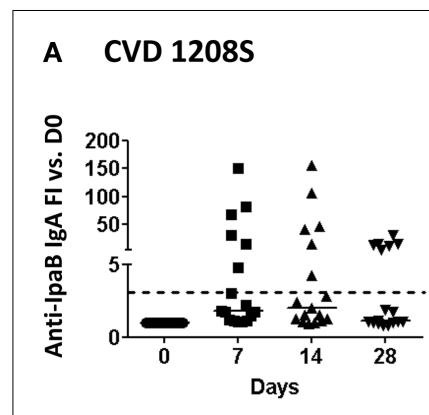

E CVD 1208S

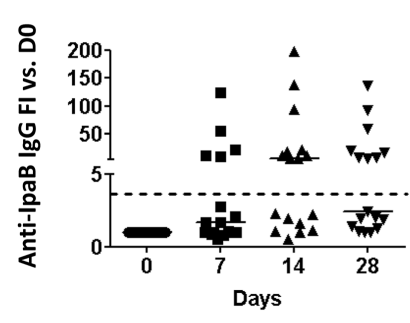

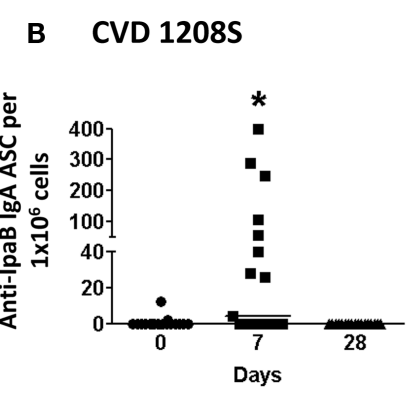

F CVD 1208S

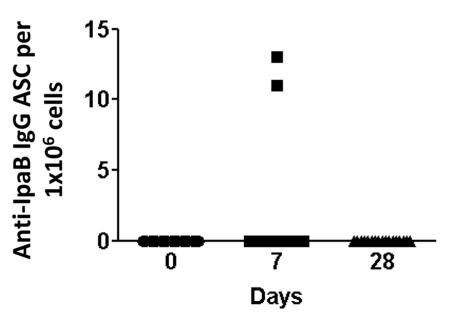

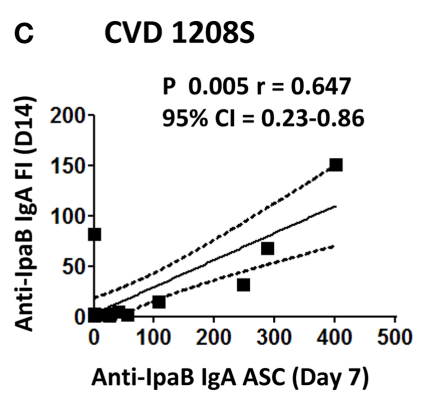

G

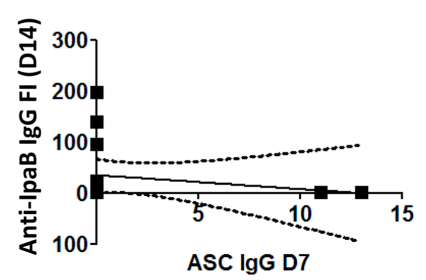

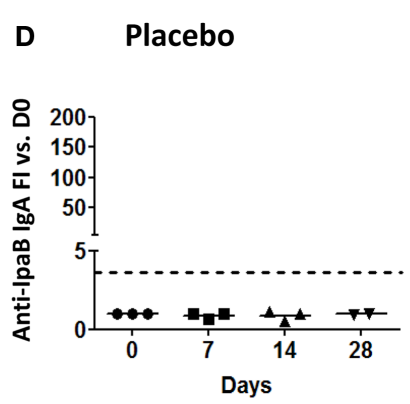

H Placebo

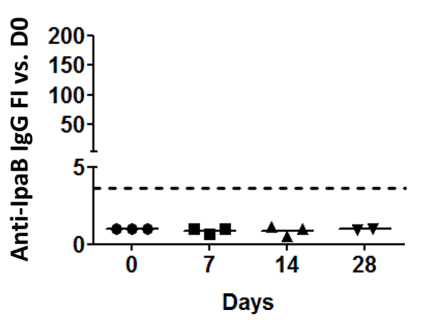

FIGURE 2 |Anti-IpaB immune responses to CVD 1208S. (A,E) Anti-LPS $\lg A$ and $\lg G$ serological responses before and at days 7, 14, and 28 after immunization. (B,F) ASC anti-LPS IgA and IgG (ELISpot) responses, respectively, before and at days 7 and 28 after immunization.

(fold-increase at day 14) and ASC (day 7). (D,H) Sera anti-LPS IgA and IgG in placebo volunteers $(n=3)$. In all plots each symbol indicates an individual volunteer. Dotted lines indicate seroconversion (fourfold-increase over day 0). Horizontal bars represent the median in all graphs. Asterisks show statistical significance when compared to day $0\left({ }^{*} p<0.05\right)$.

developed reactogenicity and those who did not. The results indicated that there were no statistically significant differences between these two groups (data not shown). Similar comparisons were performed for the other markers evaluated ( $\alpha 4 \beta 7$, CXCR3, and HLADR) but no significant differences were identified. Finally, these markers in PB and CD27- $\mathrm{PB}$ cells were also compared between volunteers of the first and second cohort and no statistically significant differences were identified (data not shown).

\section{DISCUSSION}

Two inpatient Phase 1 trials in which 14 healthy adults received ca. $10^{9}$ cfu of the live, attenuated freshly harvested S. flexneri $2 \mathrm{a}$ vaccine candidate CVD 1208 (grown in animal-containing media) (66) or CVD 1208S (grown in animal-free media) (65) suggested that deletions in $g u a B A$, sen, and set resulted in a strain that was well-tolerated while retaining the ability to evoke an immune response. In the current study in which subjects received a freshly harvested vaccine formulation grown in an animal product-free medium not previously used in our clinical trials, a proportion of subjects experienced reactogenicity that was attributed the new growth medium. In fact, the reactogenicity reported in this manuscript was unexpected, since neither the previous two trials cited above $(65,66)$ nor a follow up clinical trial with CVD $1208 \mathrm{~S}$ prepared under GMP (manuscript in preparation) resulted in any adverse effects. Even though the present trial was halted, it provided an unprecendented opportunity to study in depth the induction of humoral immune responses to Shigella after a brief (1-4 days) exposure to an attenuated vaccine before antibiotic treatment was initiated. Furthermore, this study allowed us to evaluate the homing patterns of $\mathrm{PB}$ ( $\mathrm{CPB}$ and $\mathrm{CD} 27^{-} \mathrm{PB}$ cells) elicited by immunization.

Despite the short exposure time frame (4 days for cohort one and 1-2 days for cohort 2), CVD 1208 S elicited both anti-LPS and anti-IpaB antibodies (IgA and IgG) with the LPS responses being more prominent (Figures 1 and 2; Table 2) (65). The cells responsible for the initial production of antigen-specific antibodies are PB (60) and consistent with this phenomenon, anti-LPS-ASC IgA and IgG (at day 7) correlated with anti-LPS IgA and IgG antibody titers (FI at day 14), respectively (Figures 1C,G). Similarly, anti-IpaB IgA ASC correlated with antibody titers (IgA at day 7) (Figure 2C). Anti-IpaB IgG ASC were detected only in a few volunteers, although significantly higher antibody titers were detected by ELISA. This suggests that there are still limitations in the assays used to detect $\mathrm{PB}$, particularly for poorly immunogenic antigens (e.g., IpaB), and that a complete assessment of the immune responses can only be achieved by combining the results from multiple assays. In the present studies, anti-LPS responses appeared to be transitory since IgA and IgG titers increased on days 7 and 14, but began to decrease by day 28 . On the other hand, anti-IpaB IgA and IgG antibody titers remained elevated up to day 28 (the last time evaluated). These results confirm and extend previously published data $(65,66)$.

The seroconversion rate induced by CVD $1208 \mathrm{~S}$ in this trial ( $70 \%$ for anti-LPS IgA) is similar to the one we previously reported for CVD 1208 (71\%) (66) and higher than in a previous CVD 1208 S trial (14\%) (65). Therefore, these results indicate that in the present studies CVD 1208S appeared to be similar, or more, immunogenic than previous trials, suggesting that the enhanced 


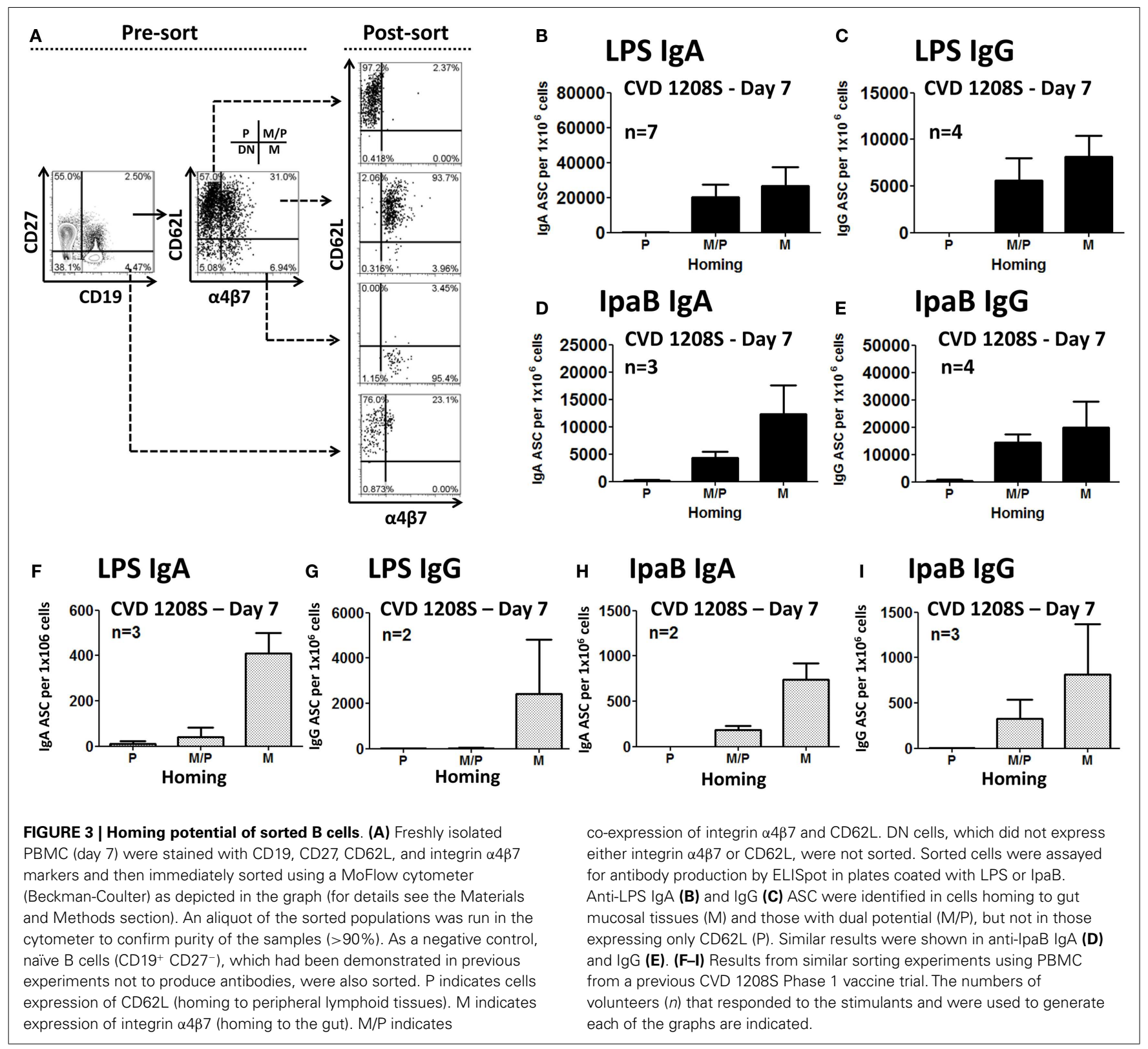

immunogenicity could be attributed to reactogenicity; however, this does not appear to be the case since no differences in the strength of the immune responses were observed between the volunteers with and without reactogenicity. Additionally, CVD $1208 \mathrm{~S}$ appears to be at least as immunogenic as other live-attenuated oral vaccines, such as Ty21a, the licensed oral attenuated typhoid vaccine, which typically exhibits a seroconversion rate of $40-60 \%$ (73-75).

Several reports have shown that $\mathrm{PB}$ cells appear in peripheral blood on day 7 post-infection or vaccination $(45,53,60,72)$. Consistent with these observations, we identified LPS- and IpaBspecific (IgA and IgG) ASC (ELISpot) on day 7 post-vaccination. Furthermore, $\mathrm{PB}$ cells are believed to ultimately migrate and home in the gut mucosa, the environment where they will produce antibodies. It is widely accepted that expression of integrin $\alpha 4 \beta 7$

promotes migration of cells to intestinal sites, while expression of CD62L promotes migration to peripheral lymphoid tissues, particularly lymph nodes. Consistent with this hypothesis, we found that sorted ASC that expressed either integrin $\alpha 4 \beta 7$ alone or in combination with CD62L, but not the ones that expressed only CD62L were responsible for antigen-specific antibody production, providing the first direct evidence of the relevance of gut-homing in subjects orally immunized with attenuated Shigella vaccines (Figures 3B-E). Of importance, similar results, albeit at lower intensity, were obtained in a previous Phase I clinical trial (CVD 24000) (Figures 3F-I).

We used multichromatic flow cytometry to characterize in depth the expression of homing markers by PB cells. Homing markers were assayed at various time points (days 0,7 , and 28) to determine differences in expression as the humoral immune 


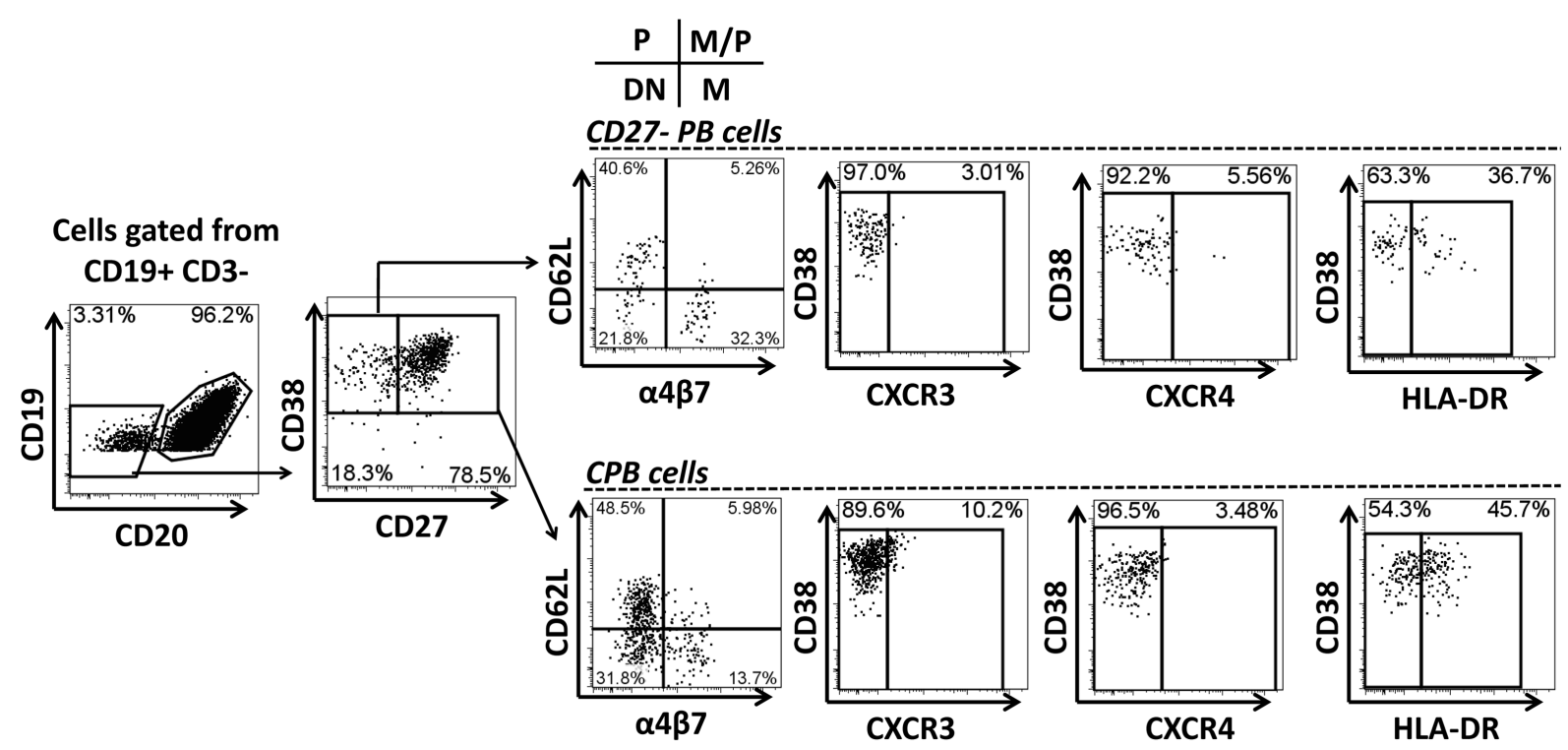

FIGURE 4 | Gating strategy for "conventional plasmablast" (CPB) and "CD27- plasmablast" (CD27- PB) cells. Example of gating strategy used (day 0 ) in a representative volunteer. CPB cells were defined as CD19 dim

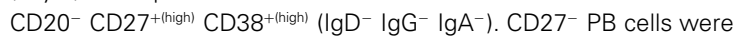
defined as $\mathrm{CD}_{19^{\text {dim }}} \mathrm{CD}^{2} \mathrm{O}^{-} \mathrm{CD}^{-} 7^{-} \mathrm{CD} 38^{\text {thigh) }}\left(\operatorname{lgD} \mathrm{D}^{-} \lg \mathrm{g}^{-} \lg \mathrm{A}^{-}\right)$. Expression of the homing molecules integrin $\alpha 4 \beta 7$ and $\mathrm{CD} 62 \mathrm{~L}$ was determined in both subpopulations. P indicates cells expressing only CD62L, which home preferentially to peripheral lymphoid tissues. M indicates cells expressing only integrin $\alpha 4 \beta 7$, homing preferentially to the gut mucosa. M/P indicates cells co-expressing integrin $\alpha 4 \beta 7$ and $\mathrm{CD} 62 \mathrm{~L}$ (dual homing potential). DN indicates cells expressing neither CD62L nor integrin $\alpha 4 \beta 7$. Expression of other homing molecules including CXCR3 and CXCR4 as well as the activation marker HLA-DR were also evaluated in CD27-PB and CPB subsets.
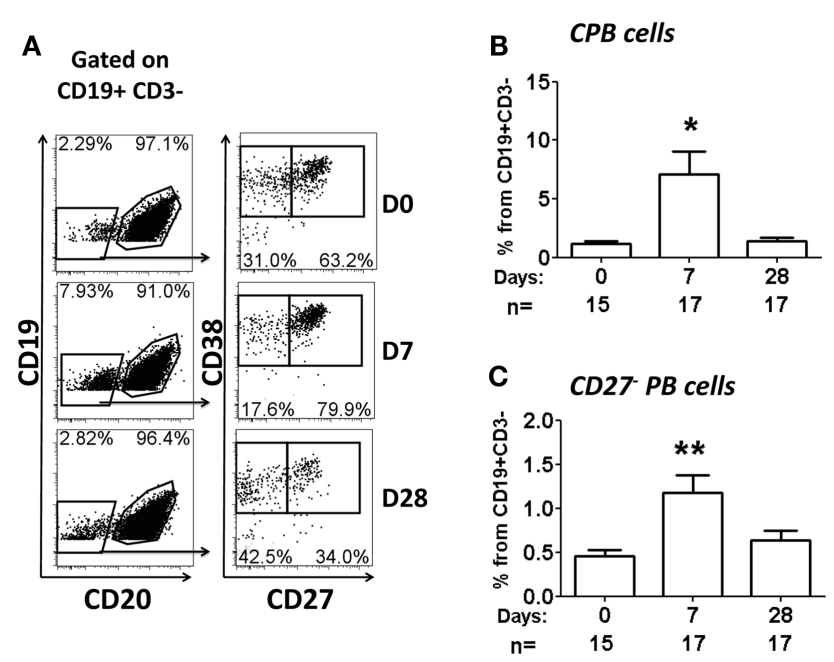

FIGURE 5 | Percentage of CPB and CD27- PB cells following oral immunization. (A) Example of population gating (CPB and $\mathrm{CD} 27^{-} \mathrm{PB}$ cells) at different time points (days 0,7 , and 28 ) in a representative vaccinated volunteer. (B,C) Show a compilation of the percentage of CPB and CD27$\mathrm{PB}$ (as percentage of $\mathrm{CD} 19^{+} \mathrm{CD}^{-}$), respectively, from all vaccinees. Bars indicate arithmetic mean $( \pm S E M)$. Asterisks show statistical significance when compared to day $0\left({ }^{*} p<0.05 ;{ }^{* *} p<0.005\right)$.

responses were developing. $\mathrm{PB}$ cell were defined as $\mathrm{CD} 19^{\mathrm{dim}}$ $\mathrm{CD}^{-} 0^{-} \mathrm{CD} 27^{+ \text {(high) }} \mathrm{CD} 38^{+ \text {(high) }} \mathrm{CD}^{-}$and referred to as $\mathrm{CPB}$, due to the identification of a second group of $\mathrm{PB}$ cells that
Table 3 | Correlation between anti-Shigella-LPS-ASC responses and changes in the percentages of CPB or CD27- PB cells.

\begin{tabular}{|c|c|c|c|}
\hline \multirow{2}{*}{ Correlated groups $^{a}$} & \multicolumn{3}{|c|}{ All volunteers } \\
\hline & $\mathbf{P}^{\mathbf{d}}$ & $\mathbf{r}^{\mathbf{e}}$ & $\mathrm{Cl}^{\mathrm{f}}$ \\
\hline$\alpha$-LPS IgA ASC (D7) and \% CPB ${ }^{b}(D 7)$ & 0.0292 & 0.857 & $0.15-0.98$ \\
\hline$\alpha$-LPS IgG ASC (D7) and \% CPB (D7) & 0.0005 & 0.754 & $0.43-0.9$ \\
\hline$\alpha$-LPS IgA ASC (D7) and \% CD27-PB ${ }^{c}$ (D7) & 0.0312 & 0.5231 & $0.05-0.80$ \\
\hline$\alpha$-LPS IgG ASC (D7) and \% CD27-PB (D7) & 0.0103 & 0.604 & $0.17-0.8$ \\
\hline
\end{tabular}

${ }^{a}$ Spearman's correlation coefficient was used.

${ }^{b} \% C P B=\%$ of conventional plasmablast cells from the $C D 19^{+}$gate.

c\% CD27- $P B=\%$ of $C D 27$ - plasmablast cells from the $C D 19^{+}$gate.

${ }^{d} P$ value.

eSpearman's rho.

${ }^{f}$ Confidence Interval.

lacked the expression of $\mathrm{CD} 27$, which were referred as $\mathrm{CD} 27^{-}$ PB (Figure 4). CPB cells not only increased in frequency by day 7 post-immunization (Figures 5A,B), but also exhibited increased expression of integrin $\alpha 4 \beta 7$, while the expression of CD62L declined, further supporting the hypothesis that these cells ultimately migrate to the intestinal mucosa (Figures $6 \mathrm{~A}, \mathrm{C}$ ). Another homing marker that was increased in $\mathrm{CPB}$ cells on day 7 was CXCR3, which promotes migration to inflamed tissues (Figures 8A,B) $(50,64)$. Thus, it is reasonable to speculate that following vaccination with an attenuated strain of Shigella, a mild inflammation of the gut mucosa would further promote 


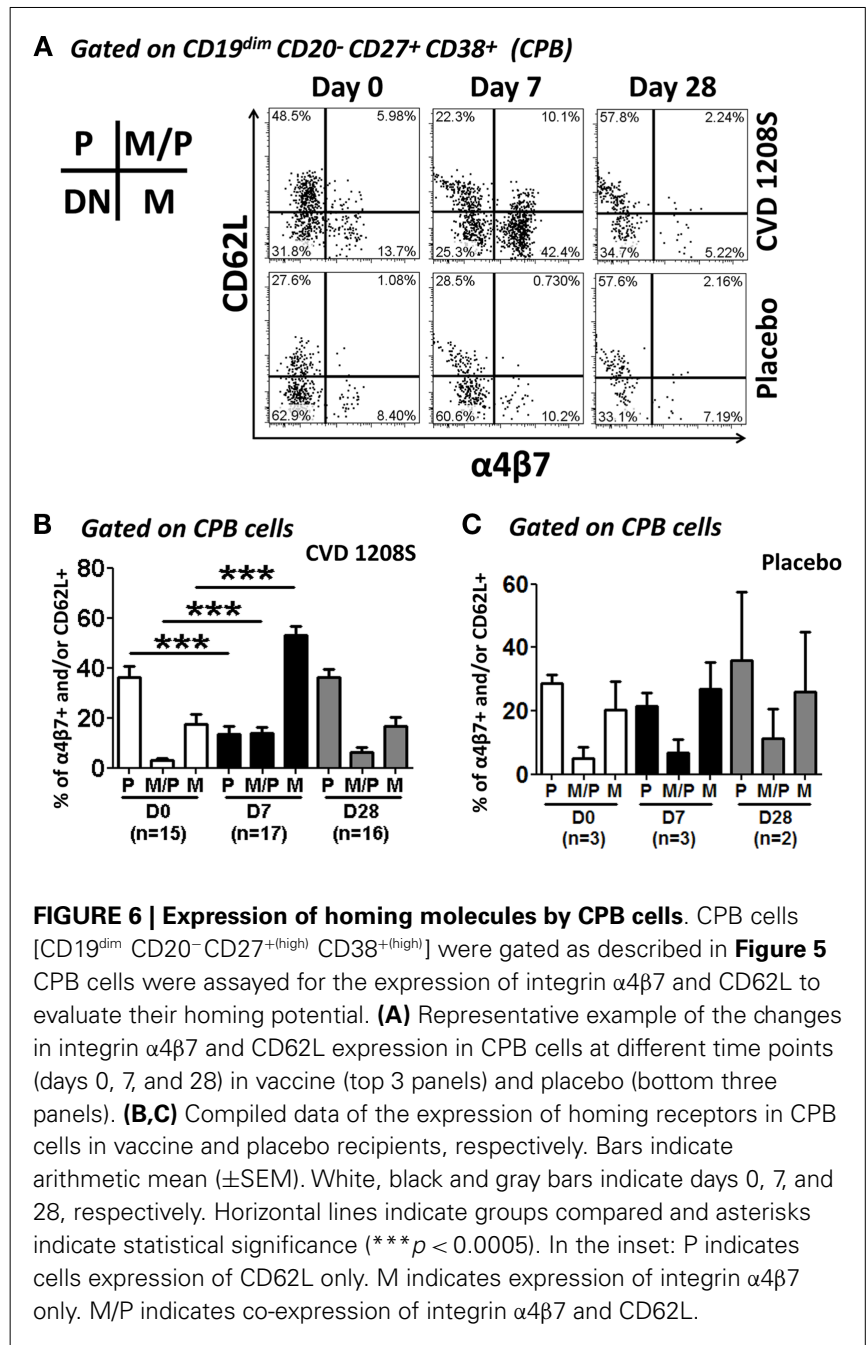

CPB cells to home in those sites. Not surprisingly, CPB cells also showed increased levels of activation on day 7 post-vaccination as evidenced by the upregulation of HLA-DR (Figures 8C,D), a phenomenon also associated with differentiation into PC (54). Interestingly, no changes were noted in the expression of CXCR4 (data not shown), a chemokine that favors homing in the bone marrow. This observation suggests that few, if any, of the CPB induced by a mucosal pathogen (or vaccine) will home in the bone marrow. The preferred homing site of these cells remains to be identified. The lack of expression of CXCR4 and increased expression of integrin $\alpha 4 \beta 7$ also suggest that most CPB produce IgA as proposed by recent studies (54). Spearman's correlation analysis suggested that the CPB cells identified by flow cytometry were indeed those detected by ELISpot assays (ASC) (Table 3). Finally, analysis of co-expression of homing molecules indicated that the vast majority of these cells express either integrin $\alpha 4 \beta 7$ alone or in combination with other homing marker(s) (Figure 9), further confirming that these cells are likely to migrate to the intestinal mucosa and inflamed tissues (combined CPB expressing integrin $\alpha 4 \beta 7$ alone or with other markers was found to be $\sim 80$ ). Therefore, it appears that only $\sim 20 \%$ of CPB elicited after

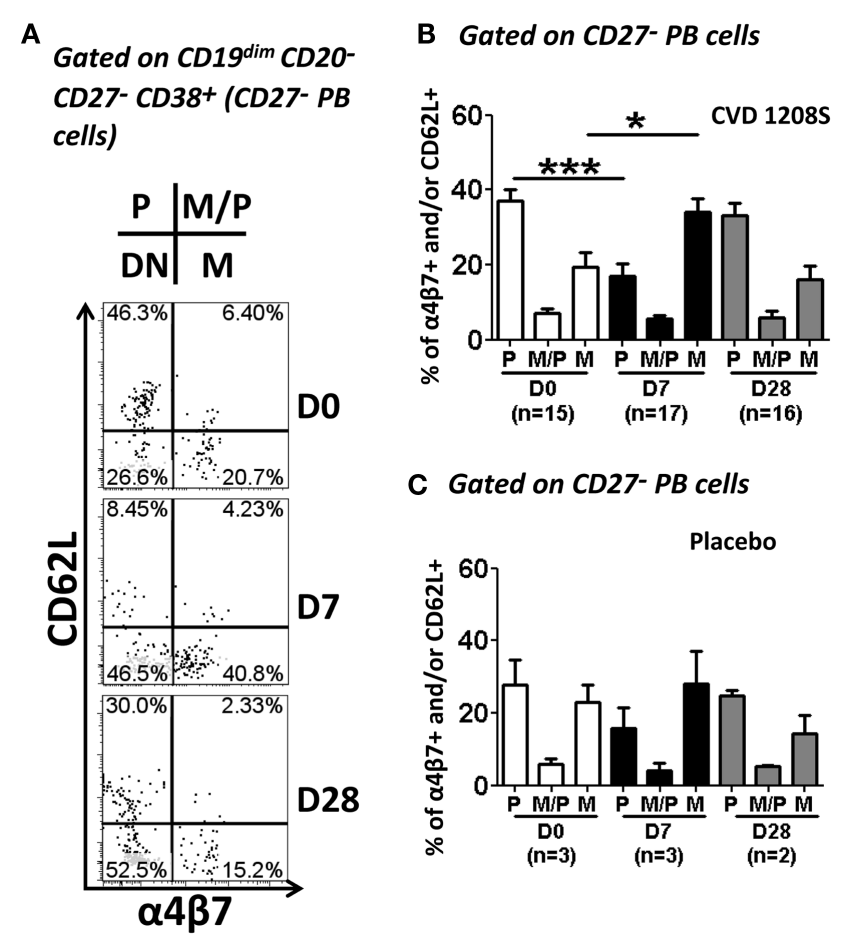

FIGURE 7 | Expression of homing molecules by CD27- PB cells. CD27 PB cells [CD19dim CD20- D27- ${ }^{-}$CD38+(high) $]$were gated as indicated in Figure 4. Similar to CPB cells, CD27- $P B$ cells were evaluated for the expression of CD62L and integrin $\alpha 4 \beta 7$ to determine their homing potential (A-C). (A) Representative example of the increase in integrin $\alpha 4 \beta 7$ and reduction of $\mathrm{CD} 62 \mathrm{~L}$ at day 7 . $(\mathbf{B}, \mathbf{C})$ Compiled data of all vaccinated $\mathbf{( B )}$ and placebo (C) volunteers at each time point evaluated. White, black and gray bars indicate days 0,7 , and 28, respectively. Bars in plots indicate arithmetic mean $( \pm$ SEM). Horizontal lines indicate groups compared and asterisk indicate statistical significance $\left({ }^{*} p<0.05 ;{ }^{* * *} p<0.0005\right)$. mucosal immunization migrate to tissues other than the intestinal mucosa.

Interestingly, we identified a population of $\mathrm{PB}$ that lacked CD27 expression (CD27- $\mathrm{PB}$; CD $19^{\text {dim }} \mathrm{CD} 20^{-} \mathrm{CD} 27^{-} \mathrm{CD} 38^{+ \text {(high); }}$ Figure 4). These cells are likely to represent the recently described pre-plasmablast population $(76,77)$. However, to our knowledge, this is the first report describing that these cells are elicited by oral immunizations in humans. CD27 ${ }^{-}$PB cells were less frequent than $\mathrm{CPB}$ (Figure 5C) and showed a somewhat similar pattern of expression of homing and activation markers than CPB (Figures 7-9). Despite the fact that integrin $\alpha 4 \beta 7$ was also an important homing marker (alone or combined $\sim 30-35 \%$ ) in $\mathrm{CD} 27^{-} \mathrm{PB}$ cells, in contrast to $\mathrm{CPB}$, the largest percentage of $\mathrm{CD}^{-} \mathrm{PB}$ expressed none of the homing markers examined ( $\sim 40-50 \%$ were quadruple negative for integrin $\alpha 4 \beta 7, \mathrm{CD} 62 \mathrm{~L}$, CXCR3, and CXCR4) (Figure 9). This suggests that even though some CD27- $\mathrm{PB}$ cells home in the intestinal mucosa, about half of these cells home in a different lymphoid organ (likely not the bone marrow), which at present remains unknown. Alternatively, since $\mathrm{CD}^{-} 7^{-} \mathrm{PB}$ are a pre-plasmablast population, the lack of expression of integrin $\alpha 4 \beta 7$ might be a consequence of their immature state 


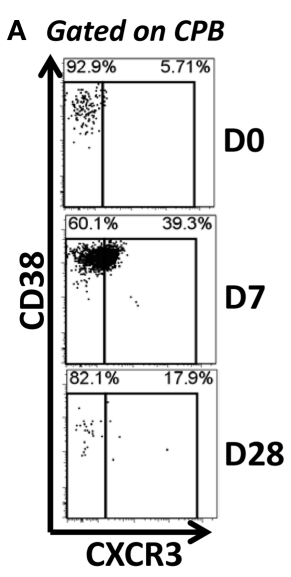

E

Gated on CD27-PB

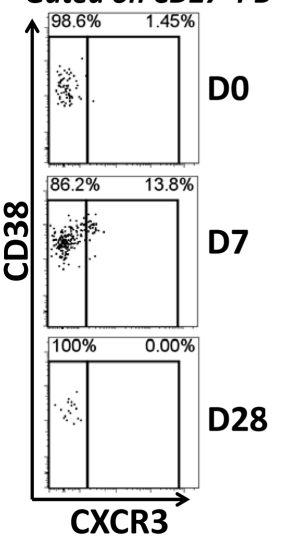

FIGURE 8 | Expression of CXCR3 and HLA-DR in CPB and CD27- PB cells. $\mathrm{CPB}$ and $\mathrm{CD}^{2} 7^{-} \mathrm{PB}$ cells (Figure 5) were also evaluated for the expression of CXCR3 and HLA-DR. Representative examples of the changes in CXCR3 $(\mathbf{A}, \mathbf{E})$ and HLA-DR $(\mathbf{C}, \mathbf{G})$ expression at the evaluated time points (Days 0,7 ,

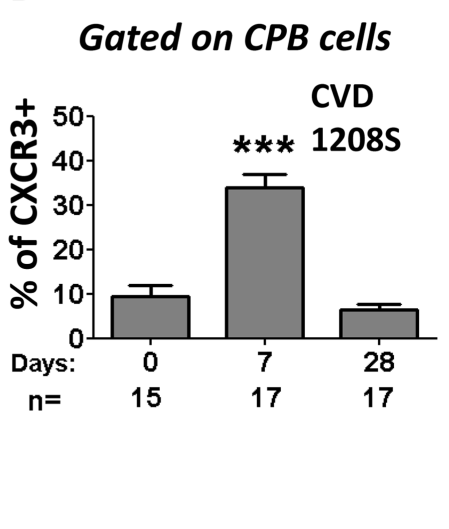

$\mathbf{F}$

Gated on CD27- PB cells

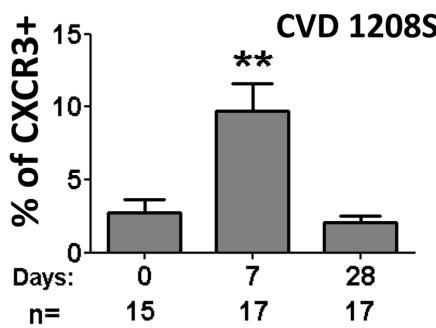

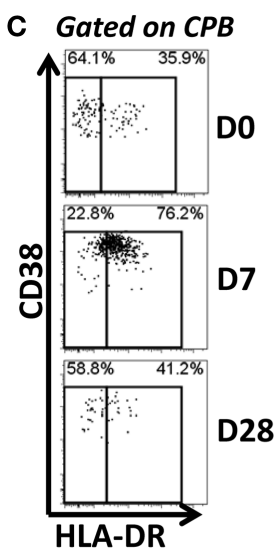

D

G

and when these cells differentiate into $\mathrm{CPB}$, increased expression of integrin $\alpha 4 \beta 7$ facilitates migration to the gut.

The severity of the disease induced by natural Shigella infections could have an impact on the strength of the immune responses elicited; however, it is unknown whether more severe disease (or vaccine reactogenicity) is associated with either enhanced or reduced immunogenicity. This is particularly important in vaccine development, since the goal is to develop immunogenic vaccines that do not produce reactogenicity; however, this balance has been difficult to achieve for Shigella. Since some vaccinated volunteers exhibited side effects, we investigated whether there was an association between reactogenicity and the strength and quality of the humoral immune responses elicited. Interestingly, no statistically significant differences were observed among the subjects who developed symptomatology and those who remained asymptomatic for any of the parameters evaluated (e.g., antibody titers, ASC frequencies, homing potential of ASC, degrees of activation), although the sample sizes were small. Another interesting observation derived from these studies relates to the early antibiotic treatment, which was initiated 1-4 days after immunization in all volunteers. Based on the strong humoral immune responses observed, it is reasonable to hypothesize that a relatively short period of exposure to an attenuated Shigella vaccine ( $\sim 1-4$ days) is sufficient to elicit strong immunity. A recent report in the $S$. typhimurium mouse model suggested that oral treatment with ciprofloxacin resulted in impaired development of the adaptive immunity (78). However, this does not appear to be the case in the current study since oral antibiotic treatment with ciprofloxacin (500 mg BID for 5 days) did not impair the development of the strong humoral immune responses.

In sum, we have shown the induction of robust antibody and ASC responses in subjects orally immunized with the attenuated Shigella vaccine strain CVD 1208 S and characterized in detail the kinetics and homing potential of $\mathrm{CPB}$ and $\mathrm{CD} 27^{-} \mathrm{PB}$ elicited by vaccination. The observations that strong immune responses were elicited in individuals who did not show reactogenicity and that a short period of exposure (1-4 days) was sufficient to elicit appropriate humoral immunity, provides further impetus for the continuing development of attenuated Shigella strains to be used as oral vaccines. 


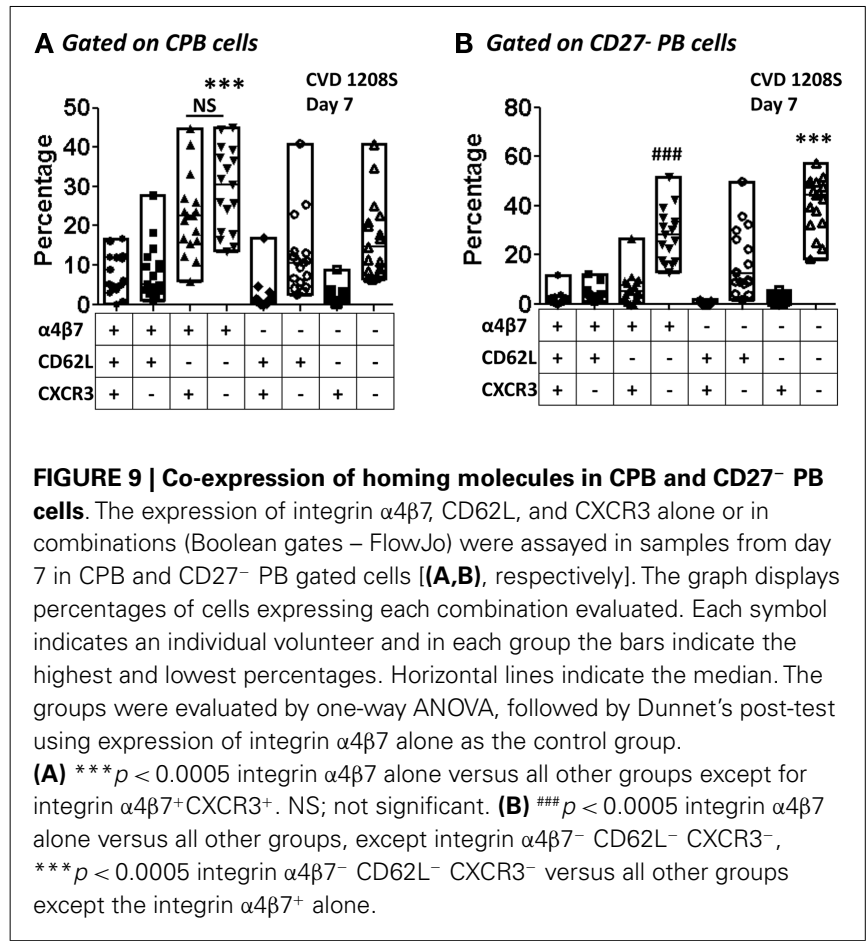

\section{ACKNOWLEDGMENTS}

We are indebted to the volunteers who participated in the studies, Robin Barnes, Lisa Chrisley, and the CVD staff for their contributions to the recruitment, assessment, and care of volunteers, and to the members of the Safety Monitoring Committee (Wilbur Chen, Alan Cross, and Robert Edelman) for their oversight and thoughtful recommendations. We also thank Catherine Storrer, Regina Harley, Mardi Reymann, Ifavet Mayo, and Jeffrey Floyd for outstanding technical support. This work was supported by the National Institutes of Health Cooperative Center for Translational Research in Human Immunology and Biodefense (CCHI) U19 AI082655 and R01-AI057927 to Marcelo B. Sztein as well as by GAT.1371-07839-CTA (Program for Appropriate Technology in Health, PATH) to Myron M. Levine. The content is solely the responsibility of the authors and does not necessarily represent the official views of the National Institute of Allergy and Infectious Diseases or the National Institutes of Health or other granting institutions.

\section{REFERENCES}

1. Fagarasan S, Honjo T. Intestinal IgA synthesis: regulation of front-line body defences. Nat Rev Immunol (2003) 3(1):63-72. doi:10.1038/nri982

2. Brandtzaeg P. Update on mucosal immunoglobulin A in gastrointestinal disease. Curr Opin Gastroenterol (2010) 26(6):554-63. doi:10.1097/MOG. 0b013e32833dccf8

3. Rescigno M, Di Sabatino A. Dendritic cells in intestinal homeostasis and disease. J Clin Invest (2009) 119(9):2441-50. doi:10.1172/jci39134

4. Sigmundsdottir H, Butcher EC. Environmental cues, dendritic cells and the programming of tissue-selective lymphocyte trafficking. Nat Immunol (2008) 9(9):981-7. doi:10.1038/ni.f.208

5. Mora JR, von Andrian UH. Differentiation and homing of IgA-secreting cells. Mucosal Immunol (2008) 1(2):96-109. doi:10.1038/mi.2007.14mi200714

6. Salmi M, Jalkanen S. Lymphocyte homing to the gut: attraction, adhesion, and commitment. Immunol Rev (2005) 206:100-13. doi:10.1111/j.0105-2896.2005. 00285.x
7. Bowman EP, Kuklin NA, Youngman KR, Lazarus NH, Kunkel EJ, Pan J, et al. The intestinal chemokine thymus-expressed chemokine (CCL25) attracts IgA antibody-secreting cells. J Exp Med (2002) 195(2):269-75. doi:10.1084/jem. 20010670

8. Kunkel EJ, Butcher EC. Plasma-cell homing. Nat Rev Immunol (2003) 3(10):822-9. doi:10.1038/nri1203nri1203

9. Berlin C, Berg EL, Briskin MJ, Andrew DP, Kilshaw PJ, Holzmann B, et al. Alpha 4 beta 7 integrin mediates lymphocyte binding to the mucosal vascular addressin MAdCAM-1. Cell (1993) 74(1):185-95. doi:10.1016/0092-8674(93)90305-A

10. Mebius RE, Dowbenko D, Williams A, Fennie C, Lasky LA, Watson SR. Expression of GlyCAM-1, an endothelial ligand for L-selectin, is affected by afferent lymphatic flow. J Immunol (1993) 151(12):6769-76.

11. Girard J-P, Springer TA. High endothelial venules (HEVs): specialized endothelium for lymphocyte migration. Immunol Today (1995) 16(9):449-57. doi:10. 1016/0167-5699(95)80023-9

12. Miyasaka M, Tanaka T. Lymphocyte trafficking across high endothelial venules: dogmas and enigmas. Nat Rev Immunol (2004) 4(5):360-70. doi:10.1038/ nri1354

13. Kotloff KL. Global burden of Shigella infections: implications for vaccine development and implementation of control strategies. Bull World Health Organ (1999) 77:651-66.

14. Kotloff KL, Nataro JP, Blackwelder WC, Nasrin D, Farag TH, Panchalingam S, et al. Burden and aetiology of diarrhoeal disease in infants and young children in developing countries (the Global Enteric Multicenter Study, GEMS): a prospective, case-control study. Lancet (2013) 382(9888):209-22. doi:10.1016/S01406736(13)60844-2

15. Phalipon A, Sansonetti PJ. Shigella's ways of manipulating the host intestinal innate and adaptive immune system: a tool box for survival? Immunol Cell Biol (2007) 85:119-29. doi:10.1038/sj.icb7100025

16. Sansonetti P, Phalipon A. Shigellosis: from molecular pathogenesis of infection to protective immunity and vaccine development. Res Immunol (1996) 147(89):595-602. doi:10.1016/S0923-2494(97)85227-3

17. Phalipon A, Sansonetti PJ. Shigellosis: innate mechanisms of inflammatory destruction of the intestinal epithelium, adaptive immune response, and vaccine development. Crit Rev Immunol (2003) 23(5-6):371-401. doi:10.1615/ CritRevImmunol.v23.i56.20

18. Ashida H, Ogawa M, Mimuro H, Kobayashi T, Sanada T, Sasakawa C. Shigella are versatile mucosal pathogens that circumvent the host innate immune system. Curr Opin Immunol (2011) 23(4):448-55. doi:10.1016/j.coi.2011.06.001

19. Simon JK, Maciel M Jr, Weld ED, Wahid R, Pasetti MF, Picking WL, et al. Antigenspecific IgA B memory cell responses to Shigella antigens elicited in volunteers immunized with live attenuated Shigella flexneri 2 a oral vaccine candidates. Clin Immunol (2011) 139(2):185-92. doi:10.1016/j.clim.2011.02.003

20. Simon JK, Wahid R, Maciel M Jr, Picking WL, Kotloff KL, Levine MM, et al. Antigen-specific B memory cell responses to lipopolysaccharide (LPS) and invasion plasmid antigen (Ipa) B elicited in volunteers vaccinated with liveattenuated Shigella flexneri 2a vaccine candidates. Vaccine (2009) 27(4):565-72. doi:10.1016/j.vaccine.2008.10.081

21. Wahid R, Simon JK, Picking WL, Kotloff KL, Levine MM, Sztein MB. Shigella antigen-specific B memory cells are associated with decreased disease severity in subjects challenged with wild-type Shigella flexneri 2a. Clin Immunol (2013) 148(1):35-43. doi:10.1016/j.clim.2013.03.009

22. Kotloff K. Phase 1 evaluation of a vriG deleted Shigella sonnei live, attenuated vaccine (strain WRSS1) in healthy adult volunteers. Infect Immun (2002) 70:2016-21. doi:10.1128/IAI.70.4.2016-2021.2002

23. Levine MM, Kotloff KL, Barry EM, Pasetti MF, Sztein MB. Clinical trials of Shigella vaccines: two steps forward and one step back on a long, hard road. Nat Rev Microbiol (2007) 5(7):540-53. doi:10.1038/nrmicrol662

24. Barry EM, Pasetti MF, Sztein MB, Fasano A, Kotloff KL, Levine MM. Progress and pitfalls in Shigella vaccine research. Nat Rev Gastroenterol Hepatol (2013) 10(4):245-55. doi:10.1038/nrgastro.2013.12

25. Ferreccio C, Prado V, Ojeda A, Cayyazo M, Abrego P, Guers L, et al. Epidemiologic patterns of acute diarrhea and endemic Shigella infections in children in a poor periurban setting in Santiago, Chile. Am J Epidemiol (1991) 134(6):614-27.

26. Mel DM, Terzin AL, Vuksic L. Studies on vaccination against bacillary dysentery. 3. Effective oral immunization against Shigella flexneri 2a in a field trial. Bull World Health Organ (1965) 32(5):647-55.

27. Mel D, Gangarosa EJ, Radovanovic ML, Arsic BL, Litvinjenko S. Studies on vaccination against bacillary dysentery. 6. Protection of children by oral 
immunization with streptomycin-dependent Shigella strains. Bull World Health Organ (1971) 45(4):457-64.

28. Herrington DA, Van de Verg L, Formal SB, Hale TL, Tall BD, Cryz SJ, et al. Studies in volunteers to evaluate candidate Shigella vaccines: further experience with a bivalent Salmonella typhi-Shigella sonnei vaccine and protection conferred by previous Shigella sonnei disease. Vaccine (1990) 8(4):353-7. doi:10.1016/0264-410X(90)90094-3

29. Kotloff KL. A modified Shigella volunteer challenge model in which the inoculum is administered with bicarbonate buffer: clinical experience and implications for Shigella infectivity. Vaccine (1995) 13:1488-94. doi:10.1016/0264410X(95)00102-7

30. Formal SB. Effect of prior infection with virulent Shigella flexneri 2a on the resistance of monkeys to subsequent infection with Shigella sonnei.J Infect Dis (1991) 164:533-7. doi:10.1093/infdis/164.3.533

31. Ferreccio C. Epidemiologic patterns of acute diarrhea and endemic Shigella infections in a poor periurban setting in Santiago, Chile. Am J Epidemiol (1991) 134:614-27.

32. Mallett CP, Hale TL, Kaminski RW, Larsen T, Orr N, Cohen D, et al. Intransal or intragastric immunization with proteosome-Shigella lipopolysaccharide vaccines protects against lethal pneumonia in a murine model of Shigella infection. Infect Immun (1995) 63(6):2382-6.

33. Orr N, Robin G, Lowell G, Cohen D. Presence of specific immunoglobulin Asecreting cells in peripheral blood after natural infection with Shigella sonnei. J Clin Microbiol (1992) 30:2165-8.

34. Phalipon A, Kaufmann M, Michetti P, Cavaillon JM, Huerre M, Sansonetti P, et al. Monoclonal immunoglobulin A antibody directed against serotype-specific epitope of Shigella flexneri lipopolysaccharide protects against murine experimental shigellosis. J Exp Med (1995) 182(3):769-78. doi:10.1084/jem.182.3.769

35. Cohen D, Green MS, Block C, Rouach T, Ofek I. Serum antibodies to lipopolysaccharide and natural immunity to shigellosis in an Israeli military population. J Infect Dis (1988) 157:1068-71. doi:10.1093/infdis/157.5.1068

36. Black RE. Prevention of shigellosis by a Salmonella typhi-Shigella sonnei bivalent vaccine. J Infect Dis (1987) 155:1260-5. doi:10.1093/infdis/155.6.1260

37. Cohen D. Double-blind vaccine-controlled randomised efficacy trial of an investigational Shigella sonnei conjugate vaccine in young adults. Lancet (1997) 349:155-9. doi:10.1016/S0140-6736(96)06255-1

38. Islam D, Wretlind B, Hammarstrom L, Christensson B, Lindberg AA. Semiquantitative estimation of Shigella antigen-specific antibodies: correlation with disease severity during shigellosis. APMIS (1996) 104(7-8):563-74. doi:10.1111/j. 1699-0463.1996.tb04912.x

39. Oaks EV, Hale TL, Formal SB. Serum immune response to Shigella protein antigens in rhesus monkeys and humans infected with Shigella spp. Infect Immun (1986) 53:57-63.

40. Samandari T. Production of IFN-[gamma] and IL-10 to Shigella invasins by mononuclear cells from volunteers orally inoculated with a shiga toxindeleted Shigella dysenteriae type 1 strain. J Immunol (2000) 164:2221-32. doi:10.4049/jimmunol.164.4.2221

41. Barzu S, Nato F, Rouyre S, Mazie JC, Sansonetti P, Phalipon A. Characterization of B-cell epitopes on IpaB, an invasion-associated antigen of Shigella flexneri: identification of an immunodominant domain recognized during natural infection. Infect Immun (1993) 61(9):3825-31.

42. Oberhelman R. Prospective study of systemic and mucosal immune responses in dysenteric patients to specific Shigella invasion plasmid antigens and lipopolysaccharides. Infect Immun (1991) 59:2341-50.

43. Qian Y, Wei C, Eun-Hyung Lee F, Campbell J, Halliley J, Lee JA, et al. Elucidation of seventeen human peripheral blood B-cell subsets and quantification of the tetanus response using a density-based method for the automated identification of cell populations in multidimensional flow cytometry data. Cytometry B Clin Cytom (2010) 78(Suppl 1):S69-82. doi:10.1002/cyto.b.20554

44. Kotloff KL. Evaluation of the safety, immunogenicity and efficacy in healthy adults of four doses of live oral hybrid Escherichia coli-Shigella flexneri 2a vaccine strain EcSf2a-2. Vaccine (1995) 13:495-502. doi:10.1016/0264-410X(94) 00011-B

45. Querec TD, Akondy RS, Lee EK, Cao W, Nakaya HI, Teuwen D, et al. Systems biology approach predicts immunogenicity of the yellow fever vaccine in humans. Nat Immunol (2009) 10(1):116-25. doi:10.1038/ni.1688

46. Cox RJ, Brokstad KA, Zuckerman MA, Wood JM, Haaheim LR, Oxford JS. An early humoral immune response in peripheral blood following parenteral inactivated influenza vaccination. Vaccine (1994) 12(11):993-9. doi:10.1016/ 0264-410X(94)90334-4

47. Moldoveanu Z, Clements ML, Prince SJ, Murphy BR, Mestecky J. Human immune responses to influenza virus vaccines administered by systemic or mucosal routes. Vaccine (1995) 13(11):1006-12. doi:10.1016/0264-410X(95) 00016- $\mathrm{T}$

48. Halliley JL, Kyu S, Kobie JJ, Walsh EE, Falsey AR, Randall TD, et al. Peak frequencies of circulating human influenza-specific antibody secreting cells correlate with serum antibody response after immunization. Vaccine (2010) 28(20):3582-7. doi:10.1016/j.vaccine.2010.02.088

49. He XS, Sasaki S, Narvaez CF, Zhang C, Liu H, Woo JC, et al. Plasmablast-derived polyclonal antibody response after influenza vaccination. J Immunol Methods (2011) 365(1-2):67-75. doi:10.1016/j.jim.2010.12.008

50. Odendahl M, Mei H, Hoyer BF, Jacobi AM, Hansen A, Muehlinghaus G, et al. Generation of migratory antigen-specific plasma blasts and mobilization of resident plasma cells in a secondary immune response. Blood (2005) 105(4):1614-21. doi:10.1182/blood-2004-07-2507

51. Lee FE, Halliley JL, Walsh EE, Moscatiello AP, Kmush BL, Falsey AR, et al. Circulating human antibody-secreting cells during vaccinations and respiratory viral infections are characterized by high specificity and lack of bystander effect. J Immunol (2011) 186(9):5514-21. doi:10.4049/jimmunol.1002932

52. Balakrishnan T, Bela-Ong DB, Toh YX, Flamand M, Devi S, Koh MB, et al. Dengue virus activates polyreactive, natural IgG B cells after primary and secondary infection. PLoS One (2011) 6(12):e29430. doi:10.1371/journal.pone. 0029430

53. Wrammert J, Onlamoon N, Akondy RS, Perng GC, Polsrila K, Chandele A, et al. Rapid and massive virus-specific plasmablast responses during acute dengue virus infection in humans. J Virol (2012) 86(6):2911-8. doi:10.1128/ JVI.06075-11

54. Mei HE, Yoshida T, Sime W, Hiepe F, Thiele K, Manz RA, et al. Blood-borne human plasma cells in steady state are derived from mucosal immune responses. Blood (2009) 113(11):2461-9. doi:10.1182/blood-2008-04-153544

55. Fink K. Origin and Function of Circulating Plasmablasts during Acute Viral Infections. Front Immunol (2012) 3:78. doi:10.3389/fimmu.2012.00078

56. Kantele A, Kantele JM, Savilahti E, Westerholm M, Arvilommi H, Lazarovits A, et al. Homing potentials of circulating lymphocytes in humans depend on the site of activation: oral, but not parenteral, typhoid vaccination induces circulating antibody-secreting cells that all bear homing receptors directing them to the gut. J Immunol (1997) 158(2):574-9.

57. Quiding-Jarbrink M, Nordstrom I, Granstrom G, Kilander A, Jertborn M, Butcher EC, et al. Differential expression of tissue-specific adhesion molecules on human circulating antibody-forming cells after systemic, enteric, and nasal immunizations. A molecular basis for the compartmentalization of effector B cell responses. J Clin Invest (1997) 99(6):1281-6. doi:10.1172/ JCI119286

58. Pakkanen SH, Kantele JM, Moldoveanu Z, Hedges S, Hakkinen M, Mestecky J, et al. Expression of homing receptors on IgA1 and IgA2 plasmablasts in blood reflects differential distribution of IgA1 and IgA2 in various body fluids. Clin Vaccine Immunol (2010) 17(3):393-401. doi:10.1128/CVI.00475-09

59. Wahid R, Simon R, Zafar SJ, Levine MM, Sztein MB. Live oral typhoid vaccine Ty21a induces cross-reactive humoral immune responses against Salmonella enterica serovar paratyphi A and S. paratyphi B in humans. Clin Vaccine Immunol (2012) 19(6):825-34. doi:10.1128/CVI.00058-12

60. Kantele A. Persistence of diarrheal pathogens is associated with continued recruitment of plasmablasts in the circulation. Clin Dev Immunol (2012) 2012:279206. doi:10.1155/2012/279206

61. Kantele A, Hakkinen M, Moldoveanu Z, Lu A, Savilahti E, Alvarez RD, et al. Differences in immune responses induced by oral and rectal immunizations with Salmonella typhi Ty21a: evidence for compartmentalization within the common mucosal immune system in humans. Infect Immun (1998) 66(12):5630-5.

62. Gonzalez AM, Jaimes MC, Cajiao I, Rojas OL, Cohen J, Pothier P, et al. Rotavirusspecific $\mathrm{B}$ cells induced by recent infection in adults and children predominantly express the intestinal homing receptor alpha4beta7. Virology (2003) 305(1):93-105. doi:10.1006/viro.2002.1708

63. Kantele JM, Arvilommi H, Kontiainen S, Salmi M, Jalkanen S, Savilahti E, et al. Mucosally activated circulating human $B$ cells in diarrhea express homing receptors directing them back to the gut. Gastroenterology (1996) 110(4):1061-7. doi:10.1053/gast.1996.v110.pm8612994 
64. Muehlinghaus G, Cigliano L, Huehn S, Peddinghaus A, Leyendeckers H, Hauser AE, et al. Regulation of CXCR3 and CXCR4 expression during terminal differentiation of memory B cells into plasma cells. Blood (2005) 105(10):3965-71. doi:10.1182/blood-2004-08-2992

65. Kotloff KL, Simon JK, Pasetti MF, Sztein MB, Wooden SL, Livio S, et al. Safety and immunogenicity of CVD 1208S, a live, oral DeltaguaBA Deltasen Deltaset Shigella flexneri 2a vaccine grown on animal-free media. Hum Vaccin (2007) 3(6):268-75. doi:10.4161/hv.4746

66. Kotloff KL. Deletion in the Shigella enterotoxin genes further attenuates Shigella flexneri 2a bearing guanine auxotrophy in a Phase 1 trial of CVD 1204 and CVD 1208. J Infect Dis (2004) 190:1745-54. doi:10.1086/424680

67. Westphal O, Jann K, Himmelspach K. Chemistry and immunochemistry of bacterial lipopolysaccharides as cell wall antigens and endotoxins. Prog Allergy (1983) 33:9-39.

68. Picking WL, Mertz JA, Marquart ME, Picking WD. Cloning, expression, and affinity purification of recombinant Shigella flexneri invasion plasmid antigens IpaB and IpaC. Protein Expr Purif (1996) 8(4):401-8. doi:10.1006/prep.1996. 0117

69. Toapanta FR, Bernal PJ, Sztein MB. Diverse phosphorylation patterns of B cell receptor-associated signaling in naive and memory human B cells revealed by phosphoflow, a powerful technique to study signaling at the single cell level. Front Cell Infect Microbiol (2012) 2:128. doi:10.3389/fcimb.2012.00128

70. McArthur MA, Sztein MB. Heterogeneity of multifunctional IL-17A producing S. typhi-specific CD8+ T cells in volunteers following Ty21a typhoid immunization. PLoS One (2012) 7(6):e38408. doi:10.1371/journal. pone. 0038408

71. El-Kamary SS, Pasetti MF, Mendelman PM, Frey SE, Bernstein DI, Treanor JJ, et al. Adjuvanted intranasal Norwalk virus-like particle vaccine elicits antibodies and antibody-secreting cells that express homing receptors for mucosal and peripheral lymphoid tissues. J Infect Dis (2010) 202(11):1649-58. doi:10.1086/657087

72. Nakaya HI, Wrammert J, Lee EK, Racioppi L, Marie-Kunze S, Haining WN, et al. Systems biology of vaccination for seasonal influenza in humans. Nat Immunol (2011) 12(8):786-95. doi:10.1038/ni.2067

73. Eloe-Fadrosh EA, McArthur MA, Seekatz AM, Drabek EF, Rasko DA, Sztein $\mathrm{MB}$, et al. Impact of oral typhoid vaccination on the human gut microbiota and correlations with S. typhi-specific immunological responses. PLoS One (2013) 8(4):e62026. doi:10.1371/journal.pone.0062026
74. Black R, Levine MM, Young C, Rooney J, Levine S, Clements ML, et al. Immunogenicity of Ty21a attenuated "Salmonella typhi" given with sodium bicarbonate or in enteric-coated capsules. Dev Biol Stand (1983) 53:9-14.

75. Forrest BD. Indirect measurement of intestinal immune responses to an orally administered attenuated bacterial vaccine. Infect Immun (1992) 60(5):2023-9.

76. Henn AD, Laski M, Yang H, Welle S, Qiu X, Miao H, et al. Functionally distinct subpopulations of CpG-activated memory B cells. Sci Rep (2012) 2:345. doi:10.1038/srep00345

77. Jackson SM, Harp N, Patel D, Wulf J, Spaeth ED, Dike UK, et al. Key developmental transitions in human germinal center B cells are revealed by differential CD45RB expression. Blood (2009) 113(17):3999-4007. doi:10.1182/blood2008-03-145979

78. Endt K, Maier L, Käppeli R, Barthel M, Misselwitz B, Kremer M, et al. Peroral ciprofloxacin therapy impairs the generation of a protective immune response in a mouse model for Salmonella enterica serovar Typhimurium diarrhea, while parenteral ceftriaxone therapy does not. Antimicrob Agents Chemother (2012) 56(5):2295-304. doi:10.1128/aac.05819-11

Conflict of Interest Statement: The Review Editor David J. M. Lewis declares that, despite having collaborated with author Myron M. Levine, the review process was handled objectively and no conflict of interest exists. Dr. Myron M. Levine, a coauthor in this manuscript, is co-inventor in a patent for the development of Gua mutants of Shigella spp. licensed to PATH. The other co-authors declared no conflict of interest.

Received: 20 May 2014; accepted: 22 July 2014; published online: 20 August 2014. Citation: Toapanta FR, Simon JK, Barry EM, Pasetti MF, Levine MM, Kotloff KL and Sztein MB (2014) Gut-homing conventional plasmablasts and CD27 plasmablasts elicited after a short time of exposure to an oral live-attenuated Shigella vaccine candidate in humans. Front. Immunol. 5:374. doi: 10.3389/fimmu.2014.00374 This article was submitted to Mucosal Immunity, a section of the journal Frontiers in Immunology.

Copyright (c) 2014 Toapanta, Simon, Barry, Pasetti, Levine, Kotloff and Sztein. This is an open-access article distributed under the terms of the Creative Commons Attribution License (CC BY). The use, distribution or reproduction in other forums is permitted, provided the original author(s) or licensor are credited and that the original publication in this journal is cited, in accordance with accepted academic practice. No use, distribution or reproduction is permitted which does not comply with these terms. 